\title{
The Role of Resveratrol in Liver Disease: A Comprehensive Review from In Vitro to Clinical Trials
}

\author{
Carmine Izzo 1,2 (D), Monica Annunziata ${ }^{1,2}$, Giuseppe Melara ${ }^{1,2}$, Roberta Sciorio ${ }^{1,2}$, Marcello Dallio ${ }^{3}$ (D), \\ Mario Masarone ${ }^{1,2}$ (D), Alessandro Federico ${ }^{3}$ (D) and Marcello Persico ${ }^{1,2, *}$
}

1 Internal Medicine and Hepatology Division, Department of Medicine and Surgery "Scuola Medica Salernitana", University of Salerno, Baronissi, 84081 Salerno, Italy; carmine.izzo93@gmail.com (C.I.); annunziata.monica@gmail.com (M.A.); gius.melara@gmail.com (G.M.); robertasciorio92@gmail.com (R.S.); mario.masarone@gmail.com (M.M.)

2 Department of Medicine, Surgery and Dentistry "Scuola Medica Salernitana", University of Salerno, Baronissi, 84081 Salerno, Italy

3 Hepatogastroenterology Division, Department of Precision Medicine, University of Campania Luigi Vanvitelli, Via Pansini 5, 80131 Naples, Italy; marcello.dallio@gmail.com (M.D.); alessandro.federico@unicampania.it (A.F.)

* Correspondence: mpersico@unisa.it; Tel.: +39-338-3338695

Citation: Izzo, C.; Annunziata, M.; Melara, G.; Sciorio, R.; Dallio, M.; Masarone, M.; Federico, A.; Persico, M. The Role of Resveratrol in Liver Disease: A Comprehensive Review from In Vitro to Clinical Trials Nutrients 2021, 13, 933

https://doi.org/10.3390/nu13030933

Academic Editor: Dominique Delmas

Received: 16 February 2021

Accepted: 11 March 2021

Published: 13 March 2021

Publisher's Note: MDPI stays neutral with regard to jurisdictional claims in published maps and institutional affiliations.

Copyright: (c) 2021 by the authors. Licensee MDPI, Basel, Switzerland. This article is an open access article distributed under the terms and conditions of the Creative Commons Attribution (CC BY) license (https:/ / creativecommons.org/licenses/by/ $4.0 /)$.
Abstract: Many studies have shown that resveratrol has a lot of therapeutic effects on liver disorders. Its administration can significantly increase the survival rate after liver transplantation, reduce fat deposition and ischemia-induced necrosis and apoptosis in Wistar rats. Resveratrol can provide Liver protection against chemical, cholestatic, and alcohol-mediated damage. It can improve glucose metabolism and lipid profile, reduce liver fibrosis, and steatosis. Additionally, it is capable of altering the fatty acid composition of the liver cells. Resveratrol may be a potential treatment option for the management of non-alcoholic fatty liver disease (NAFLD) due to its anti-inflammatory, antioxidant, and calorie-restricting effects. There are also studies that have evaluated the effect of resveratrol on lipid and liver enzyme profiles among patients with metabolic syndrome (MetS) and related disorders. Based on the extent of liver disease worldwide and the need to find new treatment possibilities, this review critically examines current in vitro and in vivo preclinical studies and human clinical studies related to liver protection.

Keywords: resveratrol; non-alcoholic fatty liver disease; nutraceutical; oxidative stress

\section{Introduction}

Resveratrol (3,5,4'-trihydroxy-trans-stilbene) is a non-flavonoid phenol produced by numerous plants in response to bacteria or fungi colonization. It can be found mainly in grape peel, blueberries, raspberries, mulberries, and peanuts while its high concentration in red wine explains, in part, the relatively low incidence of cardiovascular disease in the French population despite the prevalence of a high-fat diet (HFD) among this population [1]. Numerous studies have shown that resveratrol can prevent or slow the progression of a wide variety of diseases, including malignant tumours, neurodegenerative diseases, cardiovascular disorders, ischemic lesions, and viral infections [2-5].

Interestingly one of the most important scientific fields in this context is currently represented by its potential therapeutic effects in liver diseases [6,7].

The mechanisms underlying the beneficial effects of resveratrol have not been fully elucidated and have mainly been related to its antioxidant activity [8]. This property has been shown to protect tissues such as the liver, kidneys, and brain from a variety of types of damage caused by oxidative stress [9]. Considering the spread of liver diseasesin particular, metabolic (dysfunction) associated fatty liver disease (MAFLD) - all over the world and the necessity for new useful therapeutic approaches, efforts made by the scientific community in exploring the role of nutraceuticals in this scenario are crucial for 
assessing the applicability of the evidence obtained from in vitro and clinical trials and translating it to routine clinical practice. For these reasons, in this comprehensive review, we analyzed the current scientific knowledge about the use of resveratrol for treatment of liver diseases from in vitro models up to clinical trials.

\section{Resveratrol and Liver Disease: Molecular Mechanisms}

\subsection{Steatosis}

Obesity is a major risk factor for non-alcoholic fatty liver disease [10]. Resveratrol possesses beneficial properties that are fundamental in preventing this metabolic condition, therefore attenuating liver inflammation [11-14]. The effects of resveratrol on non-alcoholic fatty liver disease (NAFLD) are correlated to the regulation of Low-Density Lipoprotein (LDL) receptors [15].

Poulsen et al. [11] showed that resveratrol reduces the diet-induced accumulation of hepatic fat through increased oxidation of fatty acids and reductions in lipogenesis. These effects are mediated by the activation of the AMPK/SIRT1 (AMP-activated protein kinase/sirtuin 1) axis $[16,17]$. RSV (resveratrol) supplementation in rodents fed with a highfat diet demonstrated an increased number of mitochondria and, in particular, an increase in hepatic decoupling protein 2 expression, which could be involved in the normalization of the hepatic fat content [18]. Resveratrol significantly reduced TAG (triacylglycerols) and cholesterol, as well as the number and size of lipid droplets [19,20]. It would appear that a low dose of resveratrol $(0.005 \%)$ is more effective than higher doses $(0.02 \%)$ at reducing the development of hepatic steatosis, along with increases in body weight, plasma TAG levels, and total cholesterol levels [21]. The observed effects could be related to the suppression of fatty acid (FA) synthase, glucose-6-phosphate dehydrogenase, and phosphatide phosphohydrolase, whilst also partly being a consequence of the activation of FA oxidation in hepatic adipose tissue [22].

Bujanda et al. [23] investigated the action of resveratrol on hepatic steatosis in an animal model of a high carbohydrate-fat diet. They found that liver fat deposition was reduced in the resveratrol treated group $(10 \mathrm{mg} /$ day) compared to the controls. This effect was mainly related to an increase in SOD (superoxide dismutase), GPx (glutathione peroxidase), CAT (catalase), and a reduction in NOS (nitric oxide synthase) activity [23]. Focusing attention on the molecular mechanisms related to the role of resveratrol in alcoholic fatty liver disease - the activation of SIRT1 (sirtuin 1) and AMPK (AMP-activated kinase) - two critical signalling molecules that regulate the metabolic pathways of liver lipids were highlighted [24,25]. Resveratrol is a potent activator of both SIRT1 and AMPK [26]. Chronic consumption of ethanol causes an inhibition of the hepatic SIRT1-AMPK signalling system; resveratrol works by reversing this action and preventing the development of alcoholic fatty liver disease [27]. In fact, in ethanol-fed mice, RSV treatment has been shown to increase hepatic SIRT1 expression and stimulate AMPK activity, improving metabolic lipid homeostasis and antagonizing the development and progression of the disease [28].

\subsection{Oxidative Stress and Inflammation}

Resveratrol has been shown to elicit relevant antioxidant properties in a wide range of hepatic disorders [29-33]. Specifically, its effect is mainly exerted by the reduction of RNS (ROS/reactive nitrogen species), elimination of direct free radicals, and an improvement in endogenous antioxidant enzyme activity (e.g., SOD, CAT, GSH) [34,35]. Moreover, RSV promotes the synthesis of antioxidant molecules and the expression of related genes involved in the biogenesis of mitochondrial energy, mainly through the AMPK/SIRT1/Nrf2 (nuclear factor 2), ERK/p38 (signal-regulated extracellular kinase), MAPK (mitogen-activated protein kinase), and PTEN/Akt (phosphatase and tensin homolog/protein kinase B) signalling pathways. In turn, this induces autophagy through an mTOR-dependent (target of rapamycin in mammals) or TFEB-dependent (EB transcription factor) pathway [36,37]. Erythroid nuclear transcription factor-2 (Nrf2; encoded by the NFE2L2 gene in humans) is a transcription factor that regulates the gene expression of 
a large variety of antioxidant and cytoprotective enzymes through a promoter sequence called ARE (antioxidant response element) [38,39]. In this sense, resveratrol acts as an antioxidant by inhibiting Nrf2 ubiquitination, safeguarding the maintenance of its crucial functioning [40]. Nrf2, in turn, translocates into the nucleus, inducing the transcription of various antioxidant genes, such as SOD and CAT improving, then the antioxidant defence [41].

Resveratrol promotes the transcriptional functions of FoxOs (forkhead box protein O1) in order to facilitate the transcription of various antioxidant genes such as HO-1 (heme oxygenase 1) [42]. Moreover, RSV up-regulates PTEN, an important PI3K (phosphatidylinositol 3-kinase) antagonist, by blocking the activation of Akt, leading to reduced phosphorylation of FoxOs, and in turn increasing its nuclear activity [43].

The protein kinase activated by AMP (AMPK), in conditions of energy depletion, plays an important role in the regulation of energy homeostasis, tumorigenesis, and longevity, in addition to an antioxidant role, in response to resveratrol [44]. In fact, AMPK directly phosphorylates human FoxO1 in vitro and increases FoxO1-dependent transcription of manganese superoxide dismutase and catalase [30].

\subsection{Liver Fibrosis}

Oxidative stress plays a crucial role, in the NAFLD setting, promoting progression towards liver fibrosis [45]. In this regard, RSV seems to play an interesting role in the regulation of de novo fibrogenesis deposition, acting on several key pathways [46]. In fact, RSV administration reduces portal pressures, the activation of hepatic stellate cells, and improves hepatic endothelial functioning in cirrhotic rats, with an overall positive effect on cirrhosis and portal hypertension [47-49]. Specifically, the administration of resveratrol (10 and $20 \mathrm{mg} / \mathrm{kg} /$ day) to cirrhotic rats for 2 weeks showed reductions in portal pressure without significant changes in systemic hemodynamics. This effect was attributed to improved acetylcholine vasodilatory responsiveness associated with reduced production of TXA2 (thromboxane A2) and, increased endothelial NO synthesis, which is, in turn, associated with a consequential significant reduction in hepatic fibrosis. Moreover, in this complex biologic network, the well-known action of RSV on the expression of collagen-1, TGF- $\beta$ (transforming growth factor $\beta$ ), NF- $\mathrm{B}$ (nuclear factor kappa-light-chain-enhancer of activated B cells), desmin mRNA, and $\alpha$-SMA ( $\alpha$-smooth muscle actin) protein expression seems to play a crucial role in hepatocytes $[47,50,51]$.

Another interesting study, using an animal DMN (dimethyl-nitrosamine) model of liver fibrosis, demonstrated the effect of RVS in reducing the liver tissue infiltration of inflammatory cells and fibrosis deposition [52]. The molecular mechanisms highlighted as underlying this process in cultured cells of hepatocytes included reduction in MDA (malondialdehyde) levels and increases in GPx and SOD levels, as well as an inhibition of mRNA expression of inflammatory mediators, including inducible NO, TNF- $\alpha$ (tumour necrosis factor- $\alpha$ ), and IL-1 $\beta$ (interleukin-1 $\beta$ ) $[53,54]$.

\subsection{Cholestatic Liver Damage}

A cascade of inflammatory responses can lead to liver injury, through hepatic regeneration and fibrogenesis. Bile salts, associated with cholestasis, are involved in these processes.

An interesting study evaluated the hepatoprotective effects of resveratrol against cholestatic damage in a rat model via bile duct ligation. Resveratrol significantly reduced TNF- $\alpha$ and IL-6 mRNA in cultured cells of hepatocytes, reducing the number of CD68 (+) Kupffer cells recruited in the liver. In the same experimental model, there was a reduction in fibrotic tissue deposition that was mainly linked to lower TIMP-1 (tissue inhibitor of metalloproteinase-1) and collagen I $\alpha 1$ mRNA expression. These findings were associated with an increase in $\mathrm{Ki} 67$ (+) hepatocytes, thereby promoting their proliferation [55]. Another study, involving the application of a model of cholestatic liver damage induced by ANIT ( $\alpha$-naphthyl isothiocyanate), showed that resveratrol pre-treatment effectively attenuated ANIT-induced acute cholestasis and liver injury in rats [56,57]. In this setting, 
the suppression of neutrophil infiltration, and the upregulation of the expression of transporters and liver enzymes, were the mechanisms identified as being responsible for the reduction in bile acid accumulation and the related damage [58].

\subsection{Hepatocellular Carcinoma and Metastasis}

The anti-proliferative activity of resveratrol is mainly linked to triggering apoptosis of tumour cells [59-64]. Apoptosis can be activated through two main pathways: the intrinsic pathway mediated by mitochondria-apoptosomes and the extrinsic pathway induced by death receptors $[65,66]$. Activation of death receptors of the TNF (tumour necrosis factor) receptor superfamily, p. Eg, Fas (CD95/APO-1) or TRAIL (TNF-related apoptosis-inducing ligand receptors) causes the release of the caspase- 8 initiator, which can mediate the apoptosis signal through direct cleavage of downstream caspase effectors, such as caspase-3 [67]. The intrinsic pathway is triggered by the dispensing of apoptogenic factors such as Omi/HtrA2 (serine protease HTRA2, mitochondrial), Smac/DIABLO (second mitochondria-derived activator of caspases/direct IAP (apoptic protein inhibitors) binding protein with low $\mathrm{pI}$ ), cytochrome c, apoptosis-inducing factors (AIF), endonuclease G, caspase-2 and caspase-9 from the mitochondrial intermembrane space [68]. Dissemination of cytochrome $\mathrm{c}$ into the cytosol activates caspase-3 through the creation of an apoptosome complex containing cytochrome c/apoptotic protease activating factor-1 (Apaf-1)/caspase-9; Omi/HtrA2 and Smac/DIABLO encourage caspase activation by neutralizing the effects of apoptotic protein inhibitors (IAPs) [68,69]. Focusing on these mechanisms, in cultured cells of hepatocytes, resveratrol induces cancer cell death by modulating various transduction pathways through the regulation of Fas and Fas-ligand (FasL) levels [70,71]. Moreover, the ability of RSV to induce apoptosis by inhibiting the PI3K/Akt/mTOR pathway has been demostrated [72-77], thus, modulating the mitogen-activated protein kinase (MAPK) cascade $[75,76,78]$ and inhibiting the activation of NF-kB $[79,80]$. In addition, RSV's anticancer properties seem to be not only related to its biologic influence on the apoptosis cycle, as highlighted by the inhibition of signal transducers and activators of transcription 3 (STAT3) [81], a key element in tumorigenesis due to its induction of tumour cell proliferation, survival, invasion, angiogenesis, and metastasis [82,83]. A reduction in both HCC (hepatocellular carcinoma) occurrence and the number of hepatic nodules represent the basis of RSV's protective mechanisms, as highlighted in animal models using carcinogenic chemicals such as DENA (diethyl nitrosamine) [84], DENA plus phenobarbital [62,85], and DENA plus 2-AAF (2-acetylaminofluorene) [86] or transgenic mice (e.g., transgenic mice expressing the hepatitis B viral protein $(\mathrm{HBx})$ ) [87]. Dietary resveratrol restored cellular antioxidant defences, thus, reducing DENA-induced lipid peroxidation and increasing protein carbonyl formation. It also increased hepatic Nrf2 and reduced iNOS (inducible nitric oxide synthase) expression. Moreover, though its activity on Nrf2, in another experimental context, a direct anti-inflammatory effect linked to a reduction in the levels and expressions of hepatic TNF- $\alpha$, IL-1 $\beta$, and IL- 6 was highlighted [88]. Furthermore, resveratrol has been shown to elicit a remarkable anti-angiogenic effect during the development of DENA-induced hepatocellular carcinogenesis, blocking VEGF (vascular endothelial growth factor) expression through HIF-1 $\alpha$ (hypoxia-inducible factor- $1 \alpha$ ) downregulation [89]. It has also been demonstrated that resveratrol is involved in the inhibition of cell cycle progression through reductions in the levels of p34cdc2 and cyclin B1 [90]. An initial study in 2001, reported that RSV at doses of 100 and $200 \mu \mathrm{M}$ inhibited hepatoma cell proliferation and suppressed hepatoma cell invasion at concentrations of $25 \mu \mathrm{M}$ [91]. Polyphenol suppressed the expression of antioxidant proteins that protect cells from ROS or cellular oxidative damage in SK-HEP-1 cells. This occurs by repressing the expression of these proteins and, thus, resveratrol is involved in increasing the susceptibility of cancer cells to oxidative stress. Paradoxically, the molecular mechanism underlying the anti-tumour role of resveratrol is its pro-oxidant action. Furthermore, in human HepG2 cells, the anti-tumour effects of RSV were attributed to its capacity to mediate cell cycle arrest in the G1 and G2/M phases [92]. A direct link between RSV and cell proliferation was also demonstrated in another study which 
showed how resveratrol induces reductions in cyclin D1, p38 MAP kinase, Akt, and Pak1 (p21 (RAC1) activated kinase 1) expression [76].

\subsection{Hepatic Glucose Metabolism and Diabetes}

Many studies have highlighted the positive influence of resveratrol on the liver of diabetic animals $[93,94]$. In fact, resveratrol can restore the liver's regulatory role in glucose homeostasis $[95,96]$. This is associated with its ability to induce changes in the activities of carbohydrate metabolism enzymes in the livers of animals with diabetes. The molecular mechanisms behind this effect include decreasing the activity of key gluconeogenesis enzymes [97] and decreasing phosphoenolpyruvate carboxykinase protein levels, a rate-limiting enzyme for gluconeogenesis [98]. RSV also increases hexokinase and pyruvate kinase activity and decreases the activity of lactate dehydrogenase and glucose-6phosphatase [99]. Furthermore, resveratrol has been shown to increase glycogen synthase, decrease glycogen phosphorylase, and increase the glycogen content in the liver [99]. All of these effects determine a shift in the metabolic pathways towards reduced hepatic glucose production. The effects of resveratrol in the liver are also accompanied by increases in insulin concentrations in the blood, which is, which is, at least in part, also responsible for these changes [100]. Therefore, the role of resveratrol in glucose metabolism is linked, first of all, to the increases in insulin levels with consequent reductions in hepatic glucose production, and secondly, to the increased use of glucose by insulin-sensitive tissues. The beneficial effects of resveratrol have also been linked to its direct and insulin-independent role in skeletal muscle and liver [101]. This property is accompanied by an antioxidative and anti-inflammatory effect of resveratrol and a further beneficial effect of resveratrol on metabolic disorders.

\subsection{Chemical Liver Injury}

Rivera et al. [102] examined the effect of resveratrol on CCI4-induced hepatotoxicity (carbon tetrachloride). After liver CCl4-induced damage, in cultured cells of hepatocytes, lipid peroxidation and $\gamma$-glutamyl transpeptidase activity are significantly increased [103]. In this context, resveratrol partially prevents increases in lipid peroxidation and $\gamma$-glutamyl transpeptidase [104]. Additionally, this effect was obtained at a dose of $50 \mathrm{mg} / \mathrm{kg} /$ day for 14 days in a model of chemically induced acute liver injury [105]. These hepatoprotective effects are associated with the antioxidant and cleansing properties of RSV, through a reduction in the activity of xanthine oxidase, a partial restoration of GSH, in addition to its ability to inhibit apoptosis $[105,106]$. Resveratrol has also been shown to be protective against heat stress-induced hepatic damage [107]. Therefore, the role of resveratrol in liver protection against chemical damage derives mainly from its ability to suppress oxidative stress and apoptosis.

\subsection{Resveratrol and Liver Viruses}

The ability of resveratrol to inhibit the replication of infective viral agents in Cytomegalovirus (CMV), varicella-zoster, influenza $\mathrm{A}$ and herpes simplex virus has been extensively investigated [108-111]. Nakamura et al. [112] found that resveratrol significantly influenced viral hepatitis C (HCV) RNA replication within the HuH-7 OR6-derived cell test system [112]. RSV additionally prevented the formation of hepatic steatosis in C57BL/ 6 mice infected with recombinant core HCV adenoviruses by inhibiting the expression of SIRT1 and PPAR- $\alpha$ (peroxisome proliferator-activated receptor- $\alpha$ ) [113]. In transgenic hepatitis B virus (HBV) X protein (HBx) mice, RSV at a dose of $30 \mathrm{mg} / \mathrm{kg} /$ day had beneficial pleiotropic effects on intracellular reactive oxygen species, hepatocyte proliferation, and lipogenic genes. This resulted in delayed HBx-mediated hepatocellular carcinogenesis and significantly reduced the incidence of HCC [114,115]. In contrast, in another study, RSV activated hepatitis B virus (HBV) transcription, most likely due to its ability to stimulate SIRT proteins which activate HBV gene expression [114,115]. There- 
fore, the studies conducted so far have yielded contradicting evidence on the effects of resveratrol on $\mathrm{HCV}$ and HBV.

\section{Resveratrol and Liver Disease: Scientific Evidence in Animal Models}

\subsection{Paracetamol and Resveratrol}

The most common cause of acute liver failure worldwide is the use of paracetamol [116]. Paracetamol poisoning is a form of pharmaceutical intoxication stemming from high the administration or repeated administration of this over-the-counter analgesic [117]. Known also as acetaminophen, paracetamol is a known hepatotoxin, which induces liver damage mainly by oxidative stress [118,119]. Liver damage does not result from paracetamol itself, but from one of its metabolites, NAPQI (N-acetyl-p-benzoquinone imine). NAPQI reduces the concentration of glutathione, a natural antioxidant, in the liver and causes direct damage to liver cells leading to liver failure [120]. Risk factors for toxicity include chronic excessive alcohol intake, fasting or anorexia nervosa, and the use of certain medications such as isoniazid [121]. Thanks to its free radical scavenging properties and antioxidant effects, resveratrol has been shown to elicit many hepatoprotective effects against paracetamol-mediated toxicity. Treatment of hepatocytes with resveratrol, before and after paracetamol use, showed a decrease in AST (aspartate aminotransferase), ALT (alanine aminotransferase), TNF- $\alpha$, MDA (malondialdehyde), and a reduction in neutrophil infiltration [122]. Other studies-also on mice-showed a reduction in ALT levels and interleukin 6 (IL-6) after acetaminophen-induced hepatic injury [123].

To better understand paracetamol-induced liver injury, two mouse models have been used. The two mouse strains, C57BL/ 6 and BALB/c are predominantly characterized by the development of Th1 and Th2 responses, respectively. After intraperitoneal administration of paracetamol, more severe liver damage was observed in C57BL/ 6 mice compared to $\mathrm{BALB} / \mathrm{c}$ mice. By the same modality, after intraperitoneal paracetamol administration, hepatic mRNA expression of TNF- $\alpha$ and IL- 6 was measured. TNF- $\alpha$, a pro-inflammatory marker, was highly induced $24 \mathrm{~h}$ after paracetamol administration in C57BL/ 6 mice, while there was no change in BALB/c mice. IL-6 mRNA expression, an anti-inflammatory marker, was higher in the livers of BALB/c mice than those of C57BL/ 6 mice $24 \mathrm{~h}$ after administration. Furthermore, treatment of CD-1 mice- another sensitive strain- with resveratrol, protected the mice against acetaminophen-induced liver damage, and in mice, with attenuated toxicity, both lower TNF- $\alpha$ expression and higher IL-6 expression levels were found [123].

\subsection{Ethanol and Resveratrol}

The high production of alcohol-derived acetate triggers mechanisms that promote inflammation [124-127]. The metabolic activities of cytochromes on alcohol metabolites cause the release of free radicals, which, in turn, stimulate inflammatory processes in the liver [128-130].

Studies have shown the potential therapeutic utility of resveratrol in alcohol-induced liver damage. Bujanda et al. [131] demonstrated that resveratrol administered in drinking water prevents ethanol-induced liver injury, mortality, and oxidative stress in mice. The described effects are also associated with the decrease in ALT, AST, MDA, and the reversal of the increase in IL-1 and transaminase levels induced by ethanol. Chronic alcohol intoxication was induced by the progressive administration of up to $40 \%$ alcohol in drinking water. Mice given RSV received $10 \mathrm{mg} / \mathrm{mL}$ in drinking water and were assessed through transaminases, IL-1, and TNF- $\alpha$ blood levels. Histological evaluation of liver damage was performed and survival among animals was recorded. During the 10-week course of ethanol administration, a mortality of $100 \%$ was observed in the control group, but only $50 \%$ in the resveratrol group. Resveratrol alleviated alcohol-induced fatty liver disease in male mice by increasing the activity of AMPK and SIRT1, which are involved in the control of liver lipid metabolism pathways [28]. The hepatoprotective role of resveratrol is also linked to its antioxidant properties, this is evident from studies conducted by Kasdallah- 
Grissa et al. [132,133]. In these studies, dietary resveratrol prevented ethanol-induced lipid peroxidation in rats, resulting in a decrease in MDA (Malondialdehyde) content, an indicator of oxidative stress. For this purpose, recruited male Wistar rats were divided into three groups. The control group received a daily intraperitoneal injection of $0.9 \%$ saline. The second study group of rats was injected daily with $35 \%$ ethanol at $3 \mathrm{~g} / \mathrm{kg}$ body weight. The third group was given the same dose of ethanol and supplemented with RSV $(5 \mathrm{~g} / \mathrm{kg})$ in the standard diet. The treatment lasted 6 weeks and resulted in a 51.5\% increase in MDA levels in the liver. However, in rats treated with ethanol in combination with RSV, the increase in MDA levels was significantly reduced, almost to the level observed in control rats. Resveratrol also produced an increase in antioxidant enzymes, namely SOD, catalase (CAT), and GPx.

\subsection{Resveratrol in Chemical-Induced Hepatotoxicity}

Many chemicals can cause liver damage. Resveratrol can positively contribute to this kind of chemical-induced damage. One of the hepatotoxic chemicals, cadmium, was investigated. Resveratrol in mice models treated with cadmium prevents oxidative damage and hepatotoxicity. Cadmium-induces hepatic lipid peroxidation (LP-expressed as malondialdehyde production) by decreasing GSH content and inhibiting catalase and GPx activity [134,135]. Pre-administration of RSV (20 mg/kg body weight, per os)/daily to male mice, for 3 days, followed by $(7 \mathrm{mg} / \mathrm{kg}$ b.w., subcutaneous) cadmium chloride, compared to control animals, showed a reduction in glutathione (GSH), catalase (CAT), and glutathione peroxidase (GPx) levels in liver homogenates [134,135].

Another hepatotoxic chemical of interest is naphthalene. Naphthalene-induced liver damage and resveratrol hepatoprotective pharmacological effects have been investigated in mice. Treatment with resveratrol for 30 days reversed the increase in AST and ALT enzyme activity, as well as the cytokine levels of TNF- $\alpha$, IL-1 $\beta$, and IL-6, while improving total antioxidant capacity [136]. A single administration of resveratrol immediately following pyrogallol administration attenuated pyrogallol-induced hepatotoxicity and increased oxidative stress in mice. Resveratrol reduced AST and ALT levels, as well as the bilirubin concentration while increasing GSH content. Resveratrol also reduced the pyrogallol-induced increase in the activity of the metabolizing enzymes CYP1A2 (cytochrome P450 1A2) and CYP2E1 (cytochrome P450 2E1) [137]. A recent study by Farghali et al. [138] demonstrated that administration of resveratrol attenuated inflammation in d-galactosamine-sensitive and LPS-induced hepatitis [139]. This was highlighted by a reduction in TBARS (thiobarbituric acid reactive substances), AST, ALT, conjugated dienes, and bilirubin levels.

\subsection{Resveratrol in Liver Damage Induced by Atherogenic Diet}

High content atherogenic diets induce significant liver damage in both humans and laboratory animals and are responsible for fatty liver disease [140,141]. Studies have demonstrated the hepatoprotective effects of resveratrol in the high-fat dietary model of liver damage [142-145].

Ahn et al. [146] showed that resveratrol added to the diet of mice significantly reduced lipid, triglyceride, and cholesterol levels, while also suppressing the diet-induced high-fat expression of genes involved in lipid metabolism. The addition of resveratrol in high-fat diet-fed rats, after 8 -weeks of treatment prevented lipid peroxidation, reduced TNF- $\alpha$ levels, and attenuated nitric oxide synthase expression, while increasing the activity of CAT, SOD, and GPx enzymes $[23,147]$. In another study using the same experimental model [148], resveratrol not only reduced cholesterol and lipid levels but also reduced mRNA expression of HMG-CoA ( $\beta$-Hydroxy $\beta$-methylglutaryl-CoA) reductase [149]. In this study, resveratrol also increased the Apo A-l/Apo B ratio. 


\subsection{Resveratrol in Liver Ischemia-Reperfusion and Surgical Transplant}

The ischemia-reperfusion currently represents a critical event in terms of the outcome of liver transplantation [150]. Plin et al. [151] showed that resveratrol is protective against injury caused by ischemia-reperfusion in rats. The study evaluated the role of RSV in preventing $40 \mathrm{~h}$ cold storage-induced liver injury followed by hot reperfusion. Resveratrol offered protection and prevented oxidative stress and inflammation associated with ischemia-reperfusion in rats [152]. Treatment with resveratrol prevented lipid peroxidation, and enhanced SOD, CAT, and GPx activity, reducing aminotransferase levels, suppressing cytokine production, and improving vascular function $[153,154]$. The anti-inflammatory, antioxidant, and pro-apoptotic actions of resveratrol represent the basis of its positive effect on the transplanted rat liver (allograft). Resveratrol increased survival time in rats after liver transplantation and was also associated with decreased AST activity and decresed levels of cytokines IL-2 and interferon- $\gamma$ (INF- $\gamma$ ). Resveratrol also inhibited signalling pathways, such as NF- $\mathrm{kB}$, and attenuated the expression of important signalling intermediates, such as I $\beta$ B kinase and protein kinase C Additionally, RSV also induced apoptosis in lymphocytes after liver allograft transplantation, as evidenced by an increase in the Bax/Bcl-2 (BCL2 associated X/B-cell lymphoma 2) ratio [155]. Kirimlioglu et al. [156] demonstrated the hepatoprotective and antioxidant properties of resveratrol in rats undergoing partial hepatectomy. The protective effect of resveratrol was associated with a reduction in lipid peroxidation and NO content and an increase in GSH content.

\subsection{Resveratrol in the Irradiation-Induced Liver Injury Model}

Velioğlu-Öğünç et al. [157] demonstrated the protective role of resveratrol in irradiationinduced liver damage. In this study, rats were treated with resveratrol $(10 \mathrm{mg} / \mathrm{kg} /$ day $)$ for ten days. They were then exposed to full-body radiation ( $800 \mathrm{cGy}$ ) and resveratrol treatment was continued for another 10 days after irradiation. Irradiation caused a significant decrease in glutathione levels and myeloperoxidase activity, while the collagen content increased in the liver and ileum tissues. Likewise, the plasma levels of lactate dehydrogenase and pro-inflammatory cytokines, 8-hydroxy-2'-deoxyguanosine, and apoptosis were elevated. Treatment with resveratrol reversed all of these biochemical indices, prevented lipid peroxidation in male rats undergoing X-ray irradiation, increased the GSH content, and reduced collagen levels. Its role in irradiation-induced liver damage is, therefore, essentially correlated to its antioxidant activity (Table 1). 
Table 1. Summary results of the intervention studies of Resveratrol in different models.

\begin{tabular}{|c|c|c|c|c|c|}
\hline Improvement & Model & Dosage & Mechanism & Result & Reference \\
\hline \multirow[t]{2}{*}{ Steatosis } & Rats & $10 \mathrm{mg}$ & $\begin{array}{c}\text { Increase in SOD (superoxide dismutase), } \\
\text { GPx (glutathione peroxidase), CAT (catalase) } \\
\text { and a reduction in NOS (nitric oxide } \\
\text { synthase) activity }\end{array}$ & $\begin{array}{l}\text { Reduction in fatty acid deposition } \\
\text { in liver }\end{array}$ & [23] \\
\hline & & $\begin{array}{l}\text { [16]. } 30 \mathrm{mg} / \mathrm{kg} \\
{[17] .200 \mathrm{mg} / \mathrm{kg}}\end{array}$ & $\begin{array}{l}\text { Activation of the AMPK/SIRT1 (AMP } \\
\text { activated protein kinase/sirtuin 1) axis }\end{array}$ & & {$[16,17]$} \\
\hline \multirow[t]{2}{*}{$\begin{array}{l}\text { Oxidative stress and } \\
\text { inflammation }\end{array}$} & & [36]. $500 \mathrm{mg}$ od for six months & $\begin{array}{l}\text { AMPK/SIRT1/Nrf2, ERK/p38, MAPK and } \\
\text { PTEN/Akt signaling pathways, inducing } \\
\text { autophagy through an mTOR-dependent or } \\
\text { TFEB-dependent pathway }\end{array}$ & $\begin{array}{l}\text { Synthesis of antioxidant molecules } \\
\text { and the expression of related genes } \\
\text { involved in the biogenesis of } \\
\text { mitochondrial energy }\end{array}$ & {$[36,37]$} \\
\hline & & [43]. 10 to $1000 \mu \mathrm{M} / \mathrm{L}$ & $\begin{array}{c}\text { Inhibition of the Nrf2 ubiquitination; } \\
\text { promotion of the transcriptional functions of } \\
\text { FoxOs }\end{array}$ & $\begin{array}{l}\text { Induction of the transcription of } \\
\text { antioxidant genes (CAT, SOD) }\end{array}$ & [41-43] \\
\hline \multirow[t]{2}{*}{ Liver fibrosis } & Rats & $\begin{array}{l}\text { [47]. } 10 \text { to } 20 \mathrm{mg} / \mathrm{kg} \text { od } \\
\text { [50]. } 25 \text { to } 150 \mu \mathrm{M} / \mathrm{L} \mathrm{od}\end{array}$ & $\begin{array}{c}\text { Reduction in MDA (malondialdehyde) } \\
\text { levels and increase in GPx and SOD levels, } \\
\text { as well as the inhibition of mRNA } \\
\text { expression of inflammatory mediators, } \\
\text { including inducible NO, TNF- } \alpha \text { (tumor } \\
\text { necrosis factor- } \alpha \text { ), and IL-1 } \beta \\
\text { (interleukin-1 } \beta \text { ) }\end{array}$ & Reduction in portal pressure & {$[47,50,51]$} \\
\hline & & $\begin{array}{l}\text { [52]. } 20 \mathrm{mg} / \mathrm{kg} \text { od for } 3 \text { weeks } \\
\text { [54]. } 20 \mathrm{mg} / \mathrm{kg} 3 \text { days per week }\end{array}$ & $\begin{array}{l}\text { Reduction in MDA levels and increase in } \\
\text { GPx and SOD levels; } \\
\text { inhibition of mRNA expression of } \\
\text { inflammatory mediators (iNOS, TNF- } \alpha \\
\text { IL-1 } \beta \text { ) }\end{array}$ & $\begin{array}{l}\text { Reducing the liver tissue } \\
\text { infiltration of inflammatory cells } \\
\text { and fibrosis deposition }\end{array}$ & [52-54] \\
\hline \multirow[t]{2}{*}{$\begin{array}{l}\text { Cholestatic liver } \\
\text { damage }\end{array}$} & $\begin{array}{l}\text { Rat model of bile duct } \\
\text { ligation }\end{array}$ & & $\begin{array}{l}\text { Reduction in TNF- } \alpha \text { and IL- } 6 \text { mRNA levels } \\
\text { and in the number of CD68 (+) Kupffer cells } \\
\text { recruited in the liver }\end{array}$ & Reduction in cholestatic damage & [55] \\
\hline & & & $\begin{array}{c}\text { Reduction in TIMP-1 and collagen I } \alpha 1 \\
\text { mRNA expression; } \\
\text { increase of Ki67-positive hepatocytes }\end{array}$ & $\begin{array}{l}\text { Reduction in fibrotic tissue } \\
\text { deposition }\end{array}$ & [55] \\
\hline
\end{tabular}


Table 1. Cont.

\begin{tabular}{|c|c|c|c|c|c|}
\hline Improvement & Model & Dosage & Mechanism & Result & Reference \\
\hline \multirow[t]{4}{*}{$\begin{array}{l}\text { Hepatocellular } \\
\text { carcinoma } \\
\text { and metastasis }\end{array}$} & & $\begin{array}{l}\text { [70]. Increasing doses of RSV, } \\
\text { ranging from } 4 \text { to } 32 \mu \mathrm{M} / \mathrm{L} \\
\text { [75]. } 40 \mu \mathrm{M} / \mathrm{L}\end{array}$ & $\begin{array}{c}\text { Regulation of Fas and FasL levels; } \\
\text { inhibition of the PI3K/Akt/mTOR pathway; } \\
\text { inhibition of NF-KB }\end{array}$ & Induction of apoptosis & $\begin{array}{c}{[70-72,77]} \\
{[75,76,78]} \\
{[79,80]}\end{array}$ \\
\hline & $\begin{array}{l}\text { Animal models exposed } \\
\text { to carcinogenic chemicals } \\
\text { (DENA) }\end{array}$ & $\begin{array}{l}\text { [86]. } 60 \mathrm{mg} / \mathrm{kg} \text { od } \\
\text { [88]. } 50 \mathrm{mg} / \mathrm{kg}\end{array}$ & $\begin{array}{l}\text { Reduction in DENA-induced lipid } \\
\text { peroxidation, iNOS; } \\
\text { increase in protein carbonyl formation, Nrf2; } \\
\text { reduction in the expression of hepatic } \\
\text { TNF- } \alpha, \text { IL-1 } \beta \text {, and IL-6 }\end{array}$ & $\begin{array}{c}\text { Restoring of cellular } \\
\text { antioxidant defenses } \\
\text { Direct anti-inflammatory effect }\end{array}$ & [86-88] \\
\hline & & $500 \mathrm{mg}$ & $\begin{array}{l}\text { Blocking of VEGFR expression through } \\
\text { HIF-1a downregulation }\end{array}$ & Antiangiogenetic effect & [89] \\
\hline & & $\begin{array}{l}\text { RSV dissolved in DMSO at a } \\
\text { concentration of } 25 \mathrm{mM}\end{array}$ & $\begin{array}{l}\text { Reduction in cyclin D1, p38 MAP kinase, } \\
\text { Akt, and Pak1 expression }\end{array}$ & Reduction in cellular proliferation & [76] \\
\hline $\begin{array}{l}\text { Hepatic glucose } \\
\text { metabolism and } \\
\text { diabetes }\end{array}$ & & $\begin{array}{c}\text { [98]. } 6 \mathrm{mg} \text { od } \\
\text { [99]. } 5 \mathrm{mg} / \mathrm{kg} \text { twice weekly for } \\
30 \text { days } \\
\text { [100]. } 10 \mathrm{mg} / \mathrm{kg} \text { od }\end{array}$ & $\begin{array}{l}\text { Decreased activity of lactate dehydrogenase, } \\
\text { glucose-6-phosphatase, glycogen } \\
\text { phosphorylase, and reduction in } \\
\text { phosphoenolpyruvate carboxykinase } \\
\text { protein levels; } \\
\text { increases in hexokinase and pyruvate kinase } \\
\text { activity, glycogen synthase. }\end{array}$ & Increased insulin metabolism & [97-100] \\
\hline Chemical liver injury & $\begin{array}{l}\text { Carbon } \\
\text { tetrachloride-induced } \\
\text { hepatotoxicity }\end{array}$ & [105]. 25/50/75/100 $\mu \mathrm{M} / \mathrm{L}$ & $\begin{array}{l}\text { Prevention of the increase in lipid } \\
\text { peroxidation and } \gamma \text {-glutamyl } \\
\text { transpeptidase activity }\end{array}$ & $\begin{array}{l}\text { Antioxidant and } \\
\text { antiapoptotic effect }\end{array}$ & [103-106] \\
\hline
\end{tabular}

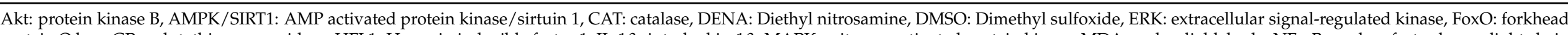

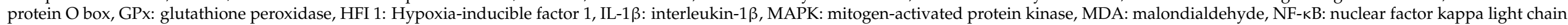

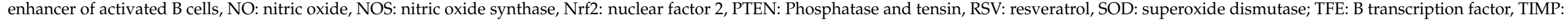
metallopeptidase inhibitor 1, TNF- $\alpha$ : tumor necrosis factor- $\alpha$, VEGFR: vascular endothelial growth factor receptor. 


\section{Liver Disease and Resveratrol: Clinical Trials}

\subsection{Resveratrol and Non-Alcoholic Fatty Liver Disease}

Non-alcoholic fatty liver disease (NAFLD) affects up to 30\% of adults in Western countries and at least $15 \%$ in Asian countries. It is the most common form of liver disease worldwide and its prevalence is expected to increase in years to come [158]. NAFLD is characterized by the accumulation of excessive fat in the liver, mainly due to pathological processes such as triglycerides accumulation, steatosis, and non-alcoholic steatohepatitis (NASH) $[159,160]$. NAFLD and NASH can ultimately develop into cirrhosis and result in liver failure [161]. In the United States NAFLD is the third most common cause of liver transplant [162]. NAFLD falls under metabolic risk factors such as insulin resistance, DM (diabetes mellitus), hyperlipidaemia, cardiovascular diseases, and chronic kidney disease $[163,164]$.

The clinical studies conducted so far have generally been too short to reveal noticeable impacts on liver structure. In fact, even in a 3-month study with $150 \mathrm{mg}$ of resveratrol administrated daily to overweight or obese insulin-resistant patients with NAFLD, no effect was highlighted in terms of liver fat content or cardio-metabolic markers [165]. This study, although conducted using a large sample size did not take into consideration the importance of the dose-dependent effect of resveratrol due to its low bioavailability [166].

The dose of $150 \mathrm{mg}$ may was probably too low. Several systematic meta-analyses have shown poor or no effects of resveratrol on the reduction in liver enzymes, anthropometric parameters, and/or blood chemistry values $[167,168]$. On the other hand, another analysis showed an interesting reduction in TNF- $\alpha$ in NAFLD patients [169]. A recent meta-analysis on 17 double-blind, randomized, placebo-controlled clinical trials showed beneficial effects [166], in particular, a significant reduction in blood pressure levels. This was highlighted by a meta-regression analysis of longer periods treatments, and inevitably, the highlighted results were supported by a dose-response relationship effect [170].

A clinical trial with a micronized formulation of trans-resveratrol in NAFLD patients highlighted promising results and therefore bodes well for the treatment of this condition. In fact, this better absorbable formulation exerted beneficial effects reducing liver fat, AST, ALT, GGT (gamma glutamyl transferase), and insulin resistance levels. Although the treatment duration, resveratrol dose, and formulation could have been the cause of these effects, the patient sample size was too small to confirm this [171]. This elucidates the conclusion that liver macro-modification requires long-term high-dose/good-bioavailability resveratrol treatment in NAFLD patients. Obviously, many more clinical studies are required to confirm this evidence.

\subsection{Effect of Resveratrol on Diabetes Mellitus}

The most important biological consequences of diabetes are mainly due to the disturbance in oxidative balance, strictly linked to the pathogenesis of several disease-related complications $[172,173]$. Resveratrol improves endothelial function, increases the oxidation of fatty acids in the liver, and decreases oxidative stress [174], leading to an improvement in insulin sensitivity [175]. A study in which 10 overweight subjects with impaired glucose tolerance were administered 1, 1.5, or $2 \mathrm{~g}$ of resveratrol daily for four weeks, participants showed an improvement in insulin sensitivity and postprandial glucose levels. In another clinical study, 17 volunteers with T2D (type 2 diabetes) were treated with $150 \mathrm{mg} /$ day of $\mathrm{RV}$ for 30 days, showing a decreased intrahepatic lipid content and systolic blood pressure. Similarly, when overweight and obese men were exposed to RSV for two weeks, $1 \mathrm{~g}$ in the first week and $2 \mathrm{~g}$ in the second one, a reduction in intestinal and hepatic lipoprotein particle production was observed. RV decreased the production rate of ApoB-48 (apolipoprotein B-48) and both the production and fractional catabolic rates of ApoB-100 (apolipoprotein B-100), compared to a placebo $[176,177]$. Similar results, with no improvement in steatosis, insulin resistance, abdominal fat distribution, and plasma lipids have been highlighted in 20 overweight/obese men with non-alcoholic fatty liver disease after receiving $3 \mathrm{~g} /$ day RSV for eight weeks [35]. Some studies have analyzed the effect of resveratrol on obesity. 
A daily RSV dose of $150 \mathrm{mg}$ /day administered for four weeks was given to 10 obese adults. Resveratrol supplementation suppressed postprandial glucagon, which may be important for the treatment of type II diabetes, as an excess of this hormone contributes to the patient's hyperglycaemia [178].

Resveratrol was also found beneficial in type 1 diabetic patients. A two-month trial with $500 \mathrm{mg}$ capsules of resveratrol, administered twice a day reported beneficial effects, such as a reduction in $\mathrm{HbA1c}$ (glycosylated haemoglobin), FBS (fasting blood sugar), and oxidative stress marker levels [179]. A recent meta-analysis even highlighted that in type 2 diabetic patients, resveratrol can reduce C-reactive protein (CRP) levels [180].

\subsection{Cancer and Resveratrol}

Thanks to their potent anti-inflammatory effect, natural compounds, such as resveratrol have gained significant attention for the treatment of many diseases, including cancer $[62,181]$. The insulin-like growth factor (IGF) signalling pathway, including IGF, IGFbinding proteins (IGFBP), and IGF receptors, is related to anticarcinogenic effects related to dietary restriction. In parallel, RSV can act as a preventive chemo-agent and caloric restriction mimetic in humans by reducing IGF-1 (insulin-like growth factor-1) and IGFBP-3 (insulin-like growth factor-binding protein 3 ) as seen in 40 healthy volunteers who consumed RSV at doses of $0.5,1.0,2.5$, or $5.0 \mathrm{~g}$ per day for 29 days, leading to a reduced risk of cancer [182]. Moreover, there was a dose-dependent effect, as the largest reduction was seen at a dose of $2.5 \mathrm{~g}$. Therefore, the preventive chemo action of RSV in humans was shown to act through the IGF system, which serves as a biomarker [183]. The only study available which has studied malignant hepatic tissue derived from patients with colorectal cancer, highlighted that $5 \mathrm{gr}$ of micronized resveratrol administered for 14 days increased both the resveratrol and cleaved caspase- 3 concentration in the malignant hepatic tissue with no safety issues [184].

\subsection{Obesity and Resveratrol}

In an 11-subject crossover study, RSV mimicked the effect of calorie restriction by reducing metabolic rate, activating AMPK in the muscle, and increasing levels of SIRT1 and peroxisome activity. It also increased citrate synthase activity and decreased the content of lipids within the liver, circulating glucose levels, triglycerides, alanine aminotransferase, and other inflammation markers. The evaluation index of the homeostatic model was also improved after the intervention [185]. To analyze the long-term effects of various polyphenols on the metabolic profile, RSV supplements and epigallocatechin-3-gallate ( 80 and $282 \mathrm{mg} /$ day, respectively) were administered to 38 overweight or obese subjects over a period of 12 weeks. An increase in mitochondrial capacity and stimulation of fat oxidation was observed, along with an improved oxidative capacity of skeletal muscles and preservation of fasting and postprandial fat oxidation. Consequently, the concentration of triacylglycerol remained unchanged after RSV treatment, unlike in the placebo group, however, no improvement in insulin resistance was found in the peripheral, hepatic, or adipose tissues [186]. Unfortunately, a randomized, double-blind, and placebo-controlled clinical trial in overweight and insulin-resistant patients who received resveratrol at a dose of 75-150 mg/day for 12 weeks showed no effect on Liver fat content [165]. A recent meta-analysis of randomized controlled trials in patients with metabolic syndrome showed that resveratrol significantly reduced not only the total cholesterol levels, but also increased GGT, with an overall potential cardioprotective effect [187].

\subsection{Effect of Resveratrol on Other Health Conditions Associated with Oxidative Stress and Inflammation}

The antioxidant effects of RSV have been extensively highlighted in the literature. In a study involving 10 healthy subjects, the administration of a single dose of $5 \mathrm{~g}$ RSV showed a significant increase in tumour necrosis factor- $\alpha$ (TNF- $\alpha$ ) in patients' plasma after $24 \mathrm{~h}$. This increased production of TNF- $\alpha$, as well as the inhibition of IL-10, was confirmed by analysis of peripheral blood mononuclear cells (PBMCs), which were activated through 
several toll receptor agonists [188]. In a separate trial, RSV's effect on immune cells was evaluated in nine healthy men and women who ingested $1 \mathrm{~g} /$ day of RSV capsules for 28 days. The results showed that RSV induced an increase in circulating T cells and was consequently able to reduce the plasma levels of proinflammatory cytokines TNF- $\alpha$ and monocyte chemo-attractant protein 1. Moreover, RSV increased the antioxidant capacity of plasma with a consequent reduction in oxidative stress markers involved in DNA damage [189]. Administration of $75 \mathrm{mg} /$ day of RSV every 12 weeks to postmenopausal women with normal weight and glucose tolerance, highlighted no changes in inflammatory markers, body composition, resting metabolism, plasma lipids, in the liver, in the skeleton density muscles mass, and adipose tissue or insulin sensitivity [190]. In conclusion, patients undergoing peritoneal dialysis in oral therapy with $450 \mathrm{mg}$ of RSV delivered daily over 12 weeks, demonstrated improved urinary ultrafiltration and decreased vascular endothelial growth factor, fetal liver kinase-1, and angiopoietin- 2 (markers of angiogenesis) levels when ingested at the highest dose available [191]. A possible reason for the conflicting results could be that a low dose or a single high dose [188] has no positive effects on health and may even cause undesired effects. Results suggest that repeated and moderate administration of RSV (>450 mg) is better and safer than a single high dose [189,191] (Table 2 and Figure 1).

Table 2. Summary results of the clinical trials of Resveratrol in different models.

\begin{tabular}{|c|c|c|c|c|}
\hline Improvement & Dosage & Patients & Result & Reference \\
\hline \multirow[t]{2}{*}{ NAFLD } & $150 \mathrm{mg}$ & $\begin{array}{c}\text { Overweight or obese } \\
\text { insulin-resistant patients with } \\
\text { NAFLD }\end{array}$ & No effect on hepatic fat content & {$[165]$} \\
\hline & $\begin{array}{l}50 \mathrm{mg} \text { Group } 1 \\
200 \mathrm{mg} \text { Group } 2\end{array}$ & $\begin{array}{l}44 \text { patients, aged } 29-70 \text { years ( } n \\
=22 \text { per group) }\end{array}$ & Reduction in the liver fat & {$[171]$} \\
\hline \multirow[t]{4}{*}{ Diabetes Mellitus } & $\begin{array}{c}1 \mathrm{~g}, 1.5 \mathrm{~g} \text {, or } 2 \mathrm{~g} \text { daily for } \\
4 \text { weeks }\end{array}$ & $\begin{array}{l}10 \text { overweight subjects with } \\
\text { impaired glucose tolerance }\end{array}$ & $\begin{array}{l}\text { Improvement in insulin sensitivity } \\
\text { and postprandial glucose levels }\end{array}$ & {$[175]$} \\
\hline & $150 \mathrm{mg} /$ day for 30 days & $\begin{array}{c}17 \text { volunteers with T2D (type } 2 \\
\text { diabetes) }\end{array}$ & $\begin{array}{l}\text { Reduction in intrahepatic lipid } \\
\text { content and systolic blood pressure }\end{array}$ & {$[176,177]$} \\
\hline & $150 \mathrm{mg} /$ day for 30 days & $\begin{array}{l}\text { Evaluation of postprandial } \\
\text { plasma responses of the incretin } \\
\text { hormones and glucagon in } 10 \\
\text { obese men }\end{array}$ & $\begin{array}{l}\text { Suppression of postprandial } \\
\text { glucagon }\end{array}$ & {$[178]$} \\
\hline & $\begin{array}{l}500 \text { mg capsules, twice } \\
\text { daily for } 60 \text { days }\end{array}$ & $\begin{array}{l}13 \text { patients with T1D } \\
\text { (type } 1 \text { diabetes) }\end{array}$ & $\begin{array}{l}\text { Reduction in HbA1c (glycosylated } \\
\text { hemoglobin), FBS (fasting blood } \\
\text { sugar) and oxidative stress markers }\end{array}$ & {$[179]$} \\
\hline \multirow[t]{2}{*}{ Cancer } & $\begin{array}{l}0.5,1.0,2.5 \text {, or } 5.0 \mathrm{~g} \\
\text { per day }\end{array}$ & 40 healthy volunteers & $\begin{array}{l}\text { Anticarcinogenica and caloric } \\
\text { restriction mimetic effect by } \\
\text { reducing IGF-1 and IGFBP-3 }\end{array}$ & {$[182]$} \\
\hline & $\begin{array}{l}\text { Micronized RSV, } 5 \mathrm{~g} \\
\text { daily for } 14 \text { days }\end{array}$ & $\begin{array}{c}\text { Patients with colorectal cancer } \\
\text { and hepatic metastases } \\
\text { scheduled to undergo } \\
\text { hepatectomy }\end{array}$ & $\begin{array}{l}\text { Increase in cleaved caspase- } 3 \text {, a } \\
\text { marker of apoptosis }\end{array}$ & {$[184]$} \\
\hline \multirow[t]{2}{*}{ Obesity } & $150 \mathrm{mg} /$ day for 30 days & $\begin{array}{l}11 \text { obese men in a randomized } \\
\text { double-blind crossover study }\end{array}$ & $\begin{array}{c}\text { In muscle: activation of AMPK, } \\
\text { increased levels of SIRT1 and } \\
\text { peroxisome activity. Increase in } \\
\text { citrate synthase activity and decrease } \\
\text { in lipid content within the liver, } \\
\text { circulating glucose levels, } \\
\text { triglycerides, alanine } \\
\text { aminotransferase, and other } \\
\text { inflammation markers }\end{array}$ & {$[185]$} \\
\hline & $\begin{array}{l}\text { EGCG (epigallocatechin- } \\
\text { 3-gallate) }+\mathrm{RSV} \\
\text { ( } 282 \text { and } 80 \mathrm{mg} / \mathrm{d}, \\
\text { respectively) or placebo } \\
\text { for } 12 \mathrm{wk} \text {. }\end{array}$ & $\begin{array}{l}\text { randomized double-blind study, } \\
38 \text { overweight and } \\
\text { obese subjects }\end{array}$ & $\begin{array}{l}\text { Increase in mitochondrial capacity } \\
\text { and stimulated fat oxidation, } \\
\text { without leading to increased } \\
\text { tissue-specific insulin sensitivity }\end{array}$ & {$[186]$} \\
\hline
\end{tabular}


Table 2. Cont.

\begin{tabular}{cccc}
\hline Improvement & Dosage & Patients & Result \\
\hline $\begin{array}{c}\text { Health condition } \\
\text { associated with oxidative } \\
\text { stress and inflammation }\end{array}$ & $5 \mathrm{~g}$, single dose & $\begin{array}{c}\text { Plasma cytokine levels were } \\
\text { measured over } 48 \mathrm{~h} \text { after oral } \\
\text { administration in } \\
10 \text { healthy subjects }\end{array}$ & $\begin{array}{c}\text { Increased production of TNF- } \alpha ; \\
\text { enhanced NF- } \mathrm{KB} \text { activation }\end{array}$ \\
\hline [188] & $\begin{array}{c}\text { 1000 } \mathrm{mg} / \text { day for } \\
28 \text { days }\end{array}$ & $\begin{array}{c}\text { Repeated doses of resveratrol on } \\
\text { circulating immune cells in } \\
\text { healthy individuals }\end{array}$ & $\begin{array}{c}\text { Increase in circulating } \gamma \delta \mathrm{T} \text { cells and } \\
\text { regulatory T cells } \\
\text { Decrease in plasma levels of the } \\
\text { proinflammatory cytokines TNF- } \alpha \\
\text { and MCP-1 }\end{array}$ \\
\hline [189] \\
150 mg or 450 mg daily & $\begin{array}{c}72 \text { patients undergoing } \\
\text { peritoneal dialysis randomly } \\
\text { assigned to 12 week treatment of } \\
\text { low-dose or high-dose } \\
\text { trans-resveratrol or a placebo }\end{array}$ & $\begin{array}{c}\text { Improvement in mean net UF } \\
\text { volume and UF rate through a } \\
\text { reduction in VEGF, Flk-1 (fetal liver } \\
\text { kinase-1) and Ang-2 } \\
\text { (angiopoietin) levels }\end{array}$ \\
\hline
\end{tabular}

AMPK: AMP activated protein kinase, Ang-2: angiopoietin, FBS: fasting blood sugar, Flk-1: fetal liver kinase-1, HbA1c: glycosylated hemoglobin, IGF: insulin-like growth factor, IGFBP-3: insulin-like growth factor binding protin-3, MCP-1:monocyte chemoattractant protein-1, NAFLD: Non-alcoholic fatty liver disease, NF-kB: nuclear factor kappa light chain enhancer of activated B cells, RSV: resveratrol, SIRT1: sirtuin 1, T1D: type 1 diabetes, T2D: type 2 diabetes, TNF- $\alpha$ : tumor necrosis factor- $\alpha$, UF: ultrafiltration, VEGFR: vascular endothelial growth factor receptor.
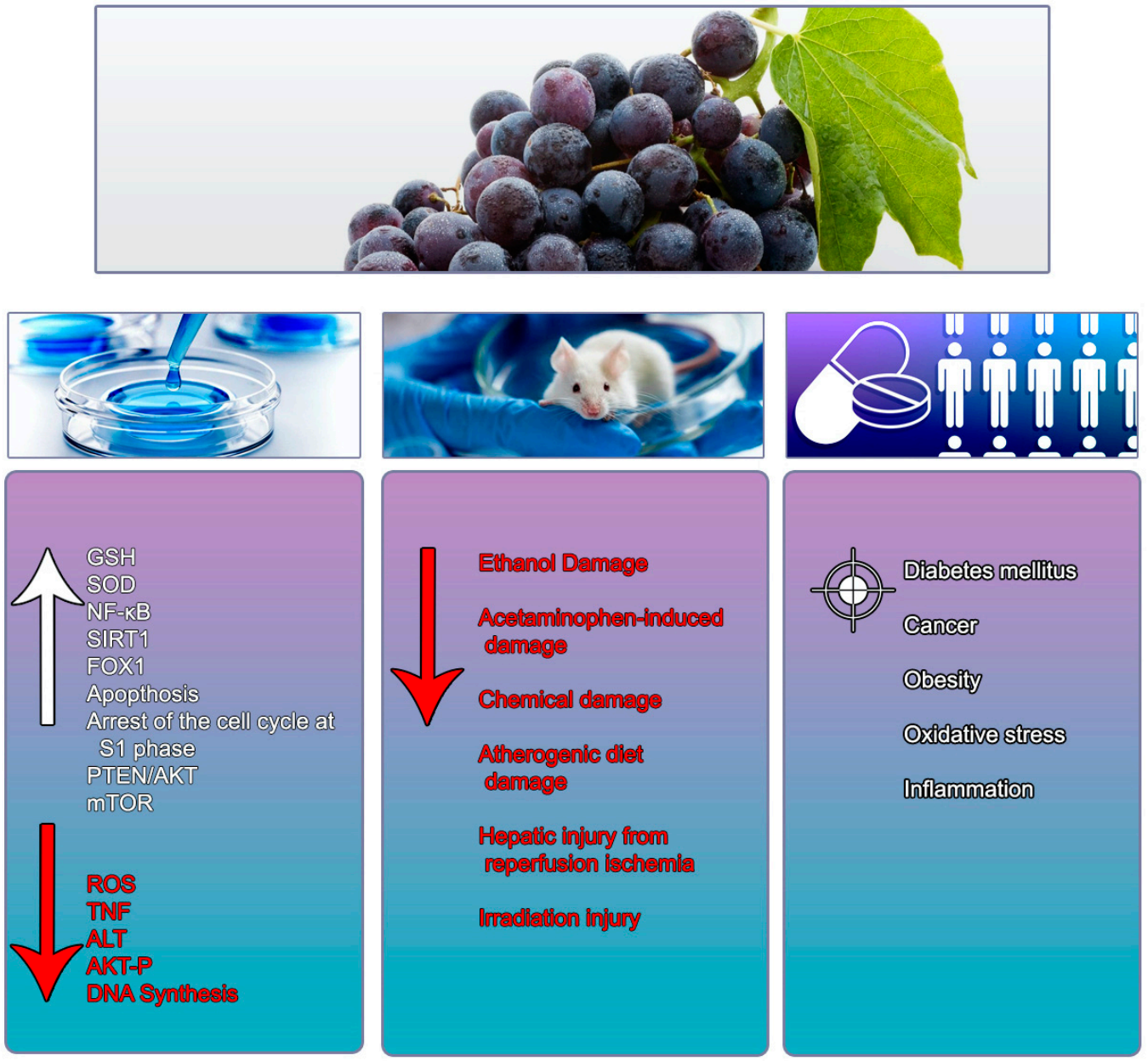

Figure 1. Summary of the main molecular mechanisms and physiological effects exerted by Resveratrol in vitro, in vivo and clinical studies. Red arrow $(\downarrow)$ indicates down-regulation; white arrow $(\uparrow)$ indicates up-regulation. GSH: glutathione; SOD: superoxide dismutase; NF-kB: nuclear factor kappa-light-chain-enhancer of activated B cells; SIRT1: sirtuin 1; FOX1: forkhead protein O box; S1:. Synthesis Phase; PTEN/AKT: phosphatase and tensin homolog/protein kinase B; mTOR: target of rapamycin in mammals; ROS: reactive oxygen species; TNF: tumor necrosis factor; ALT: alanine aminotransferase; AKT-P: protein kinase B. 


\title{
5. Conclusions, Future Perspectives and Limitations
}

Liver diseases remain a heavy health burden worldwide. This group of diseases requires new and safe therapeutic options for treatment. In this regard, resveratrol could be a promising option, as shown throughout our review.

Resveratrol is already widely used as a dietary supplement. However, studies so far have not found specific doses and administration intervals for this compound. Possible therapeutic indications of RSV would largely benefit from a targeted approach. Understanding the correct use of this molecule in the different liver pathological settings could open new therapeutic scenarios. RSV could also benefit from association therapy with other drugs and compounds. Future perspectives are promising as RSV has been shown to have various beneficial effects in vitro, in vivo, and in clinical trials. An important limitation, in addition to RSV administration, is its bioavailability [184,192,193]. Although proven safe, RSV does not have optimal pharmacokinetics and pharmacodynamics properties [194-196].

Therefore, there is still much work to be done as the remaining knowledge gaps in relation to this compound are substantial. Well-designed clinical trials are necessary to improve the bioavailability of resveratrol and to understand its precise therapeutic usefulness, correct dosage, and treatment duration.

Author Contributions: C.I. Conceptualization; C.I., M.A., G.M., R.S., and M.D. writing the article; M.M., A.F., and M.P. critical revision of the manuscript. All authors have read and agreed to the published version of the manuscript.

Funding: This research received no external funding.

Conflicts of Interest: The authors declare no conflict of interest.

\begin{abstract}
Abbreviations
AC, acetyl; AIF, apoptosis-inducing factors; Akt, protein kinase B; AMPK, AMP activated protein kinase; ANIT, $\alpha$-naphthyl isothiocyanate; APAF-1, apoptotic protease activating factor-1; ARE, antioxidant response element; ALT, alanine aminotransferase; AST, aspartate aminotransferase; Bax/Bcl-2, BCL2 Associated X/B-cell lymphoma 2; CAT, catalase; CRP, C-reactive protein; GSH, glutathione; CYP1A2, cytochrome P450 1A2; CYP2E1, cytochrome P450 2E1; DENA, Diethyl nitrosamine; DM, diabetes mellitus; DMN, dimethyl-nitrosamine; ERK, extracellular signal-regulated kinase; FA, fatty acid; FBS, fasting blood sugar; FoxO, forkhead protein O box; GGT, Gamma Glutamyl Transferase; GPx, glutathione peroxidase; G $\beta L, G$ protein similar to $\beta$ subunits; $\mathrm{HbA1c}$, glycosylated haemoglobin; $\mathrm{HBx}$, hepatitis B viral protein; HBV, hepatitis B virus; HCV, hepatitis $C$ virus; HFD, high-fat diet; HIF- $1 \alpha$, hypoxia-inducible factor- $1 \alpha$; HMG-CoA, $\beta$-Hydroxy $\beta$-methylglutaryl-CoA; HO-1, heme oxygenase 1 ; IGF, insulin-like growth factor; IL-1 $\beta$, interleukin- $1 \beta$; INF- $\gamma$, interferon- $\gamma$; Keap1, Kelch-like ECH-associated protein 1; LKB1, hepatic kinase B1; MAFLD, metabolic associated fatty liver disease; MAP2K, mitogen-activated protein kinase kinase; MAPK, mitogen-activated protein kinase; MDA, malondialdehyde; MetS, metabolic syndrome; mSIN1, mammalian stressactivated protein kinase protein kinase $1 ; \mathrm{mTOR}$, target of rapamycin in mammals; mTORC2, mTOR Complex 2; NAD, nicotinamide adenine dinucleotide; NAFLD, non-alcoholic fatty liver disease; NAPQI, N-acetyl-p-benzoquinone imine; NF- $\mathrm{B}$, nuclear factor kappa light chain enhancer of activated B cells; NASH, non-alcoholic steatohepatitis; Nrf2, nuclear factor 2; NOS, nitric oxide synthase; P, phosphorylation; p53, phosphoprotein p53; PBMCs, peripheral blood mononuclear cells; PDK1, phosphoinositide-dependent kinase 1 ; PGC- $1 \alpha$, activator of gamma receptors activated by the proliferator of peroxisome $1 \alpha$; PI3K, phosphatidylinositol 3-kinase; PIP2, phosphatidylinositol 4,5-bisphosphate; PIP3, phosphatidylinositol-3,4,5-triphosphate; PPAR- $\alpha$, peroxisome proliferatoractivated receptor- $\alpha$; PTEN, Phosphatase and tensin homolog/protein kinase B; Rictor, mTOR's rapamycin insensitive companion; SIRT1, sirtuin 1; $\alpha$-SMA, Smac/DIABLO, second mitochondriaderived activator of caspases/direct IAP binding protein with low $\mathrm{pI} ; \alpha$-smooth muscle actin; SOD, superoxide dismutase; STAT, signal transducer and transcription activator; TAG, triacylglycerols; TBARS, thiobarbituric acid reactive substances; TF, transcription factor; TFEB, EB transcription factor; TGF- $\beta$, transforming growth factor $\beta$; TIMP-1, tissue inhibitor of metalloproteinase- 1 ; TNF- $\alpha$, tumor
\end{abstract}


necrosis factor- $\alpha$; TRAIL, TNF-related apoptosis-inducing ligand receptors; TXA2, thromboxane A2; VEGF, vascular endothelial growth factor.

\section{References}

1. BedÊ, T.P.; Jesuz, V.A.; Souza, V.R.; Elias, M.B.; Oliveira, F.L.; Dias, J.F.; Teodoro, A.J.; Azeredo, V.B. Effects of Grape Juice, Red Wine and Resveratrol on Liver Parameters of Rat Submitted High-fat Diet. An. Acad. Bras. Cienc. 2020, 92, e20191230. [CrossRef]

2. Baur, J.A.; Sinclair, D.A. Therapeutic Potential of Resveratrol: The in vivo Evidence. Nat. Rev. Drug Discov. 2006, 5, 493-506. [CrossRef]

3. Shankar, S.; Singh, G.; Srivastava, R.K. Chemoprevention by Resveratrol: Molecular Mechanisms and Therapeutic Potential. Front. Biosci. 2007, 12, 4839-4854. [CrossRef]

4. Saiko, P.; Szakmary, A.; Jaeger, W.; Szekeres, T. Resveratrol and Its Analogs: Defense against Cancer, Coronary Disease and Neurodegenerative Maladies or Just a Fad? Mutat. Res. 2008, 658, 68-94. [CrossRef] [PubMed]

5. Shakibaei, M.; Harikumar, K.B.; Aggarwal, B.B. Resveratrol Addiction: To Die or not to Die. Mol. Nutr. Food Res. 2009, 53, 115-128. [CrossRef] [PubMed]

6. Kawada, N.; Seki, S.; Inoue, M.; Kuroki, T. Effect of Antioxidants, Resveratrol, Quercetin, and N-acetylcysteine, on the Functions of Cultured Rat Hepatic Stellate Cells and Kupffer Cells. Hepatology 1998, 27, 1265-1274. [CrossRef] [PubMed]

7. Bechmann, L.P.; Zahn, D.; Gieseler, R.K.; Fingas, C.D.; Marquitan, G.; Jochum, C.; Gerken, G.; Friedman, S.L.; Canbay, A. Resveratrol Amplifies Profibrogenic Effects of Free Fatty Acids on Human Hepatic Stellate Cells. Hepatol. Res. 2009, $39,601-608$. [CrossRef]

8. Berman, A.Y.; Motechin, R.A.; Wiesenfeld, M.Y.; Holz, M.K. The Therapeutic Potential of Resveratrol: A Review of Clinical Trials. NPJ Precis. Oncol. 2017, 1. [CrossRef]

9. Schmatz, R.; Perreira, L.B.; Stefanello, N.; Mazzanti, C.; Spanevello, R.; Gutierres, J.; Bagatini, M.; Martins, C.C.; Abdalla, F.H.; Daci da Silva Serres, J.; et al. Effects of Resveratrol on Biomarkers of Oxidative Stress and on the Activity of Delta Aminolevulinic Acid Dehydratase in Liver and Kidney of Streptozotocin-induced Diabetic Rats. Biochimie 2012, 94, 374-383. [CrossRef]

10. Polyzos, S.A.; Kountouras, J.; Mantzoros, C.S. Obesity and Nonalcoholic Fatty Liver Disease: From Pathophysiology to Therapeutics. Metabolism 2019, 92, 82-97. [CrossRef]

11. Poulsen, M.M.; Larsen, J.; Hamilton-Dutoit, S.; Clasen, B.F.; Jessen, N.; Paulsen, S.K.; Kjær, T.N.; Richelsen, B.; Pedersen, S.B. Resveratrol Up-regulates Hepatic Uncoupling Protein 2 and Prevents Development of Nonalcoholic Fatty Liver Disease in Rats Fed a High-fat Diet. Nutr. Res. 2012, 32, 701-708. [CrossRef]

12. Liu, C.; Liao, J.Z.; Li, P.Y. Traditional Chinese Herbal Extracts Inducing Autophagy as a Novel Approach in Therapy of Nonalcoholic Fatty Liver Disease. World J. Gastroenterol. 2017, 23, 1964-1973. [CrossRef]

13. Eseberri, I.; Lasa, A.; Miranda, J.; Gracia, A.; Portillo, M.P. Potential miRNA Involvement in the Anti-adipogenic Effect of Resveratrol and Its Metabolites. PLoS ONE 2017, 12, e0184875. [CrossRef] [PubMed]

14. Trepiana, J.; Krisa, S.; Renouf, E.; Portillo, M.P. Resveratrol Metabolites Are Able to Reduce Steatosis in Cultured Hepatocytes. Pharmaceuticals 2020, 13, 285. [CrossRef] [PubMed]

15. Xin, P.; Han, H.; Gao, D.; Cui, W.; Yang, X.; Ying, C.; Sun, X.; Hao, L. Alleviative Effects of Resveratrol on Nonalcoholic Fatty Liver Disease are Associated with up Regulation of Hepatic Low Density Lipoprotein Receptor and Scavenger Receptor Class B Type I Gene Expressions in Rats. Food Chem. Toxicol. 2013, 52, 12-18. [CrossRef] [PubMed]

16. Alberdi, G.; Rodríguez, V.M.; Macarulla, M.T.; Miranda, J.; Churruca, I.; Portillo, M.P. Hepatic Lipid Metabolic Pathways Modified by Resveratrol in Rats Fed an Obesogenic Diet. Nutrition 2013, 29, 562-567. [CrossRef]

17. Ding, S.; Jiang, J.; Zhang, G.; Bu, Y.; Zhao, X. Resveratrol and Caloric Restriction Prevent Hepatic Steatosis by Regulating SIRT1-autophagy Pathway and Alleviating Endoplasmic Reticulum Stress in High-fat Diet-fed Rats. PLoS ONE 2017, 12, e0183541. [CrossRef]

18. Trepiana, J.; Milton-Laskibar, I.; Gómez-Zorita, S.; Eseberri, I.; González, M.; Fernández-Quintela, A.; Portillo, M.P. Involvement of 5'-Activated Protein Kinase (AMPK) in the Effects of Resveratrol on Liver Steatosis. Int. J. Mol. Sci. 2018, 19, 3473. [CrossRef] [PubMed]

19. Che, Y.; Shi, X.; Zhong, X.; Zhang, Y.; Si, R.; Li, Y.; Shi, Y. Resveratrol Prevents Liver Damage in MCD-induced Steatohepatitis Mice by Promoting SIGIRR Gene Transcription. J. Nutr. Biochem. 2020, 82, 108400. [CrossRef] [PubMed]

20. Zhou, R.; Yi, L.; Ye, X.; Zeng, X.; Liu, K.; Qin, Y.; Zhang, Q.; Mi, M. Resveratrol Ameliorates Lipid Droplet Accumulation in Liver Through a SIRT1/ATF6-Dependent Mechanism. Cell. Physiol. Biochem. 2018, 51, 2397-2420. [CrossRef]

21. Khaleel, E.F.; Abdel-Aleem, G.A.; Mostafa, D.G. Resveratrol Improves High-fat Diet Induced Fatty Liver and Insulin Resistance by Concomitantly Inhibiting Proteolytic Cleavage of Sterol Regulatory Element-binding Proteins, Free Fatty Acid Oxidation, and Intestinal Triglyceride Absorption. Can. J. Physiol. Pharmacol. 2018, 96, 145-157. [CrossRef]

22. Cho, S.J.; Jung, U.J.; Choi, M.S. Differential Effects of Low-dose Resveratrol on Adiposity and Hepatic Steatosis in Diet-induced Obese Mice. Br. J. Nutr. 2012, 108, 2166-2175. [CrossRef]

23. Bujanda, L.; Hijona, E.; Larzabal, M.; Beraza, M.; Aldazabal, P.; García-Urkia, N.; Sarasqueta, C.; Cosme, A.; Irastorza, B.; González, A.; et al. Resveratrol Inhibits Nonalcoholic Fatty Liver Disease in Rats. BMC Gastroenterol. 2008, 8, 40. [CrossRef]

24. Gracia, A.; Fernández-Quintela, A.; Miranda, J.; Eseberri, I.; González, M.; Portillo, M.P. Are miRNA-103, miRNA-107 and miRNA-122 Involved in the Prevention of Liver Steatosis Induced by Resveratrol? Nutrients 2017, 9, 360. [CrossRef] 
25. Wang, L.F.; Wang, X.N.; Huang, C.C.; Hu, L.; Xiao, Y.F.; Guan, X.H.; Qian, Y.S.; Deng, K.Y.; Xin, H.B. Inhibition of NAMPT Aggravates High Fat Diet-induced Hepatic Steatosis in Mice Through Regulating Sirt1/AMPK $\alpha /$ SREBP1 Signaling Pathway. Lipids Health Dis. 2017, 16, 82. [CrossRef]

26. Izdebska, M.; Piątkowska-Chmiel, I.; Korolczuk, A.; Herbet, M.; Gawrońska-Grzywacz, M.; Gieroba, R.; Sysa, M.; Czajkowska-Bania, K.; Cygal, M.; Korga, A.; et al. The Beneficial Effects of Resveratrol on Steatosis and Mitochondrial Oxidative Stress in HepG2 Cells. Can. J. Physiol. Pharmacol. 2017, 95, 1442-1453. [CrossRef]

27. Hosseini, H.; Teimouri, M.; Shabani, M.; Koushki, M.; Babaei Khorzoughi, R.; Namvarjah, F.; Izadi, P.; Meshkani, R. Resveratrol Alleviates Non-alcoholic Fatty Liver Disease Through Epigenetic Modification of the Nrf2 Signaling Pathway. Int. J. Biochem. Cell. Biol. 2020, 119, 105667. [CrossRef]

28. Ajmo, J.M.; Liang, X.; Rogers, C.Q.; Pennock, B.; You, M. Resveratrol Alleviates Alcoholic Fatty Liver in Mice. Am. J. Physiol. Gastrointest. Liver Physiol. 2008, 295, G833-G842. [CrossRef] [PubMed]

29. Pan, Y.; Zhang, H.; Zheng, Y.; Zhou, J.; Yuan, J.; Yu, Y.; Wang, J. Resveratrol Exerts Antioxidant Effects by Activating SIRT2 To Deacetylate Prx1. Biochemistry 2017, 56, 6325-6328. [CrossRef]

30. Yun, H.; Park, S.; Kim, M.J.; Yang, W.K.; Im, D.U.; Yang, K.R.; Hong, J.; Choe, W.; Kang, I.; Kim, S.S.; et al. AMP-activated Protein Kinase Mediates the Antioxidant Effects of Resveratrol Through Regulation of the Transcription Factor FoxO1. FEBS J. 2014, 281, 4421-4438. [CrossRef]

31. Yilmaz Demirtas, C.; Bircan, F.S.; Pasaoglu, O.T.; Turkozkan, N. The Effects of Resveratrol on Hepatic Oxidative Stress in Metabolic Syndrome Model Induced by High Fructose Diet. Bratisl. Lek. Listy 2018, 119, 36-40. [CrossRef] [PubMed]

32. Carrizzo, A.; Izzo, C.; Forte, M.; Sommella, E.; Di Pietro, P.; Venturini, E.; Ciccarelli, M.; Galasso, G.; Rubattu, S.; Campiglia, P.; et al. A Novel Promising Frontier for Human Health: The Beneficial Effects of Nutraceuticals in Cardiovascular Diseases. Int. J. Mol. Sci. 2020, 21, 8706. [CrossRef]

33. Ferramosca, A.; Di Giacomo, M.; Zara, V. Antioxidant Dietary Approach in Treatment of Fatty Liver: New Insights and Updates. World J. Gastroenterol. 2017, 23, 4146-4157. [CrossRef] [PubMed]

34. Carrizzo, A.; Forte, M.; Damato, A.; Trimarco, V.; Salzano, F.; Bartolo, M.; Maciag, A.; Puca, A.A.; Vecchione, C. Antioxidant Effects of Resveratrol in Cardiovascular, Cerebral and Metabolic Diseases. Food Chem. Toxicol. 2013, 61, 215-226. [CrossRef]

35. de Oliveira, M.R.; Chenet, A.L.; Duarte, A.R.; Scaini, G.; Quevedo, J. Molecular Mechanisms Underlying the Anti-depressant Effects of Resveratrol: A Review. Mol. Neurobiol. 2018, 55, 4543-4559. [CrossRef]

36. Meng, X.; Zhou, J.; Zhao, C.N.; Gan, R.Y.; Li, H.B. Health Benefits and Molecular Mechanisms of Resveratrol: A Narrative Review. Foods 2020, 9, 340. [CrossRef] [PubMed]

37. Kulkarni, S.S.; Cantó, C. The Molecular Targets of Resveratrol. Biochim. Biophys. Acta 2015, 1852, 1114-1123. [CrossRef] [PubMed]

38. Lu, M.C.; Ji, J.A.; Jiang, Z.Y.; You, Q.D. The Keap1-Nrf2-ARE Pathway as a Potential Preventive and Therapeutic Target: An Update. Med. Res. Rev. 2016, 36, 924-963. [CrossRef]

39. Ahmed, S.M.; Luo, L.; Namani, A.; Wang, X.J.; Tang, X. Nrf2 Signaling Pathway: Pivotal Roles in Inflammation. Biochim. Biophys. Acta Mol. Basis Dis. 2017, 1863, 585-597. [CrossRef] [PubMed]

40. Zhang, P.; Li, Y.; Du, Y.; Li, G.; Wang, L.; Zhou, F. Resveratrol Ameliorated Vascular Calcification by Regulating Sirt-1 and Nrf2. Transplant. Proc. 2016, 48, 3378-3386. [CrossRef]

41. Bellezza, I.; Giambanco, I.; Minelli, A.; Donato, R. Nrf2-Keap1 Signaling in Oxidative and Reductive Stress. Biochim. Biophys. Acta Mol. Cell Res. 2018, 1865, 721-733. [CrossRef]

42. Shaw, P.; Chattopadhyay, A. Nrf2-ARE Signaling in Cellular Protection: Mechanism of Action and the Regulatory Mechanisms. J. Cell. Physiol. 2020, 235, 3119-3130. [CrossRef] [PubMed]

43. Harikumar, K.B.; Aggarwal, B.B. Resveratrol: A Multitargeted Agent for Age-associated Chronic Diseases. Cell Cycle 2008, 7, 1020-1035. [CrossRef] [PubMed]

44. McCubrey, J.A.; Lertpiriyapong, K.; Steelman, L.S.; Abrams, S.L.; Cocco, L.; Ratti, S.; Martelli, A.M.; Candido, S.; Libra, M.; Montalto, G.; et al. Regulation of GSK-3 Activity by Curcumin, Berberine and Resveratrol: Potential Effects on Multiple Diseases. Adv. Biol. Regul. 2017, 65, 77-88. [CrossRef]

45. Bae, M.; Park, Y.K.; Lee, J.Y. Food Components with Antifibrotic Activity and Implications in Prevention of Liver Disease. J. Nutr. Biochem. 2018, 55, 1-11. [CrossRef]

46. Hessin, A.F.; Hegazy, R.R.; Hassan, A.A.; Yassin, N.Z.; Kenawy, S.A. Resveratrol Prevents Liver Fibrosis via Two Possible Pathways: Modulation of Alpha Fetoprotein Transcriptional Levels and Normalization of Protein Kinase C Responses. Indian J. Pharmacol. 2017, 49, 282-289. [CrossRef]

47. Di Pascoli, M.; Diví, M.; Rodríguez-Vilarrupla, A.; Rosado, E.; Gracia-Sancho, J.; Vilaseca, M.; Bosch, J.; García-Pagán, J.C. Resveratrol Improves Intrahepatic Endothelial Dysfunction and Reduces Hepatic Fibrosis and Portal Pressure in Cirrhotic Rats. J. Hepatol. 2013, 58, 904-910. [CrossRef]

48. Xu, M.; Xue, W.; Ma, Z.; Bai, J.; Wu, S. Resveratrol Reduces the Incidence of Portal Vein System Thrombosis after Splenectomy in a Rat Fibrosis Model. Oxid. Med. Cell. Longev. 2016, 2016, 7453849. [CrossRef]

49. de Oliveira, C.M.; Martins, L.A.M.; de Sousa, A.C.; Moraes, K.D.S.; Costa, B.P.; Vieira, M.Q.; Coelho, B.P.; Borojevic, R.; de Oliveira, J.R.; Guma, F.C.R. Resveratrol Increases the Activation Markers and Changes the Release of Inflammatory Cytokines of Hepatic Stellate Cells. Mol. Cell. Biochem. 2020. [CrossRef] 
50. Zhang, D.Q.; Sun, P.; Jin, Q.; Li, X.; Zhang, Y.; Zhang, Y.J.; Wu, Y.L.; Nan, J.X.; Lian, L.H. Resveratrol Regulates Activated Hepatic Stellate Cells by Modulating NF-кB and the PI3K/Akt Signaling Pathway. J. Food Sci. 2016, 81, H240-H245. [CrossRef] [PubMed]

51. Zhu, L.; Mou, Q.; Wang, Y.; Zhu, Z.; Cheng, M. Resveratrol Contributes to the Inhibition of Liver Fibrosis by Inducing Autophagy via the microRNA-20a-mediated Activation of the PTEN/PI3K/AKT Signaling Pathway. Int. J. Mol. Med. 2020, 46, $2035-2046$. [CrossRef]

52. Abdu, S.B.; Al-Bogami, F.M. Influence of Resveratrol on Liver Fibrosis Induced by Dimethylnitrosamine in Male Rats. Saudi J. Biol. Sci. 2019, 26, 201-209. [CrossRef] [PubMed]

53. Lee, E.S.; Shin, M.O.; Yoon, S.; Moon, J.O. Resveratrol Inhibits Dimethylnitrosamine-induced Hepatic Fibrosis in Rats. Arch. Pharm. Res. 2010, 33, 925-932. [CrossRef]

54. Hong, S.W.; Jung, K.H.; Zheng, H.M.; Lee, H.S.; Suh, J.K.; Park, I.S.; Lee, D.H.; Hong, S.S. The Protective Effect of Resveratrol on Dimethylnitrosamine-induced Liver Fibrosis in Rats. Arch. Pharm. Res. 2010, 33, 601-609. [CrossRef]

55. Chan, C.C.; Cheng, L.Y.; Lin, C.L.; Huang, Y.H.; Lin, H.C.; Lee, F.Y. The Protective Role of Natural Phytoalexin Resveratrol on Inflammation, Fibrosis and Regeneration in Cholestatic Liver Injury. Mol. Nutr. Food Res. 2011, 55, 1841-1849. [CrossRef]

56. Ding, L.; Zhang, B.; Li, J.; Yang, L.; Wang, Z. Beneficial Effect of Resveratrol on $\alpha$-naphthyl Isothiocyanate-induced Cholestasis via Regulation of the FXR Pathway. Mol. Med. Rep. 2018, 17, 1863-1872. [CrossRef] [PubMed]

57. Chambers, K.F.; Day, P.E.; Aboufarrag, H.T.; Kroon, P.A. Polyphenol Effects on Cholesterol Metabolism via Bile Acid Biosynthesis, CYP7A1: A Review. Nutrients 2019, 11, 2588. [CrossRef] [PubMed]

58. Wang, T.; Zhou, Z.X.; Sun, L.X.; Li, X.; Xu, Z.M.; Chen, M.; Zhao, G.L.; Jiang, Z.Z.; Zhang, L.Y. Resveratrol Effectively Attenuates $\alpha$-naphthyl-isothiocyanate-induced Acute Cholestasis and Liver Injury Through Choleretic and Anti-inflammatory Mechanisms. Acta Pharmacol. Sin. 2014, 35, 1527-1536. [CrossRef] [PubMed]

59. Ahmad, N.; Adhami, V.M.; Afaq, F.; Feyes, D.K.; Mukhtar, H. Resveratrol Causes WAF-1/p21-mediated G(1)-phase Arrest of Cell Cycle and Induction of Apoptosis in Human Epidermoid Carcinoma A431 Cells. Clin. Cancer Res. 2001, 7, $1466-1473$.

60. Dörrie, J.; Gerauer, H.; Wachter, Y.; Zunino, S.J. Resveratrol Induces Extensive Apoptosis by Depolarizing Mitochondrial Membranes and Activating Caspase-9 in Acute Lymphoblastic Leukemia Cells. Cancer Res. 2001, 61, 4731-4739.

61. Tinhofer, I.; Bernhard, D.; Senfter, M.; Anether, G.; Loeffler, M.; Kroemer, G.; Kofler, R.; Csordas, A.; Greil, R. Resveratrol, a Tumor-suppressive Compound from Grapes, Induces Apoptosis via a Novel Mitochondrial Pathway Controlled by Bcl-2. FASEB J. 2001, 15, 1613-1615. [CrossRef] [PubMed]

62. Ko, J.H.; Sethi, G.; Um, J.Y.; Shanmugam, M.K.; Arfuso, F.; Kumar, A.P.; Bishayee, A.; Ahn, K.S. The Role of Resveratrol in Cancer Therapy. Int. J. Mol. Sci. 2017, 18, 2589. [CrossRef] [PubMed]

63. Zhang, D.; Zhang, J.; Zeng, J.; Li, Z.; Zuo, H.; Huang, C.; Zhao, X. Nano-Gold Loaded with Resveratrol Enhance the AntiHepatoma Effect of Resveratrol. J. Biomed. Nanotechnol. 2019, 15, 288-300. [CrossRef] [PubMed]

64. Karabekir, S.C.; Özgörgülü, A. Possible Protective Effects of Resveratrol in Hepatocellular Carcinoma. Iran J. Basic. Med. Sci. 2020, 23, 71-78. [CrossRef] [PubMed]

65. Okada, H.; Mak, T.W. Pathways of Apoptotic and Non-apoptotic Death in Tumour Cells. Nat. Rev. Cancer 2004, 4, 592-603. [CrossRef] [PubMed]

66. Zirbes, T.; Novotny, G.E. Quantification of Thymic Innervation in Juvenile and Aged Rats. Acta Anat. 1992, 145, 283-288. [CrossRef]

67. Ashkenazi, A.; Dixit, V.M. Apoptosis Control by Death and Decoy Receptors. Curr. Opin. Cell Biol. 1999, 11, 255-260. [CrossRef]

68. van Loo, G.; Saelens, X.; van Gurp, M.; MacFarlane, M.; Martin, S.J.; Vandenabeele, P. The Role of Mitochondrial Factors in Apoptosis: A Russian Roulette with More than One Bullet. Cell Death Differ. 2002, 9, 1031-1042. [CrossRef] [PubMed]

69. Du, C.; Fang, M.; Li, Y.; Li, L.; Wang, X. Smac, a Mitochondrial Protein that Promotes Cytochrome C-dependent Caspase Activation by Eliminating IAP Inhibition. Cell 2000, 102, 33-42. [CrossRef]

70. Clément, M.V.; Hirpara, J.L.; Chawdhury, S.H.; Pervaiz, S. Chemopreventive Agent Resveratrol, a Natural Product Derived from Grapes, Triggers CD95 Signaling-dependent Apoptosis in Human Tumor Cells. Blood 1998, 92, 996-1002. [CrossRef]

71. Delmas, D.; Rébé, C.; Lacour, S.; Filomenko, R.; Athias, A.; Gambert, P.; Cherkaoui-Malki, M.; Jannin, B.; Dubrez-Daloz, L.; Latruffe, N.; et al. Resveratrol-induced Apoptosis is Associated with Fas Redistribution in the Rafts and the Formation of a Death-inducing Signaling Complex in Colon Cancer Cells. J. Biol. Chem. 2003, 278, 41482-41490. [CrossRef] [PubMed]

72. Bai, Y.; Mao, Q.Q.; Qin, J.; Zheng, X.Y.; Wang, Y.B.; Yang, K.; Shen, H.F.; Xie, L.P. Resveratrol Induces Apoptosis and Cell Cycle Arrest of Human T24 Bladder Cancer Cells in vitro and Inhibits Tumor Growth in vivo. Cancer Sci. 2010, 101, 488-493. [CrossRef] [PubMed]

73. Aziz, M.H.; Nihal, M.; Fu, V.X.; Jarrard, D.F.; Ahmad, N. Resveratrol-caused Apoptosis of Human Prostate Carcinoma LNCaP Cells is Mediated via Modulation of Phosphatidylinositol 3'-kinase/Akt Pathway and Bcl-2 Family Proteins. Mol. Cancer Ther. 2006, 5, 1335-1341. [CrossRef] [PubMed]

74. Faber, A.C.; Dufort, F.J.; Blair, D.; Wagner, D.; Roberts, M.F.; Chiles, T.C. Inhibition of Phosphatidylinositol 3-kinase-mediated Glucose Metabolism Coincides with Resveratrol-induced Cell Cycle Arrest in Human Diffuse Large B-cell Lymphomas. Biochem. Pharmacol. 2006, 72, 1246-1256. [CrossRef]

75. Banerjee Mustafi, S.; Chakraborty, P.K.; Raha, S. Modulation of Akt and ERK1/2 Pathways by Resveratrol in Chronic Myelogenous Leukemia (CML) Cells Results in the Downregulation of Hsp70. PLoS ONE 2010, 5, e8719. [CrossRef] 
76. Parekh, P.; Motiwale, L.; Naik, N.; Rao, K.V. Downregulation of Cyclin D1 is Associated with Decreased Levels of p38 MAP Kinases, Akt/PKB and Pak1 during Chemopreventive Effects of Resveratrol in Liver Cancer Cells. Exp. Toxicol. Pathol. 2011, 63, 167-173. [CrossRef] [PubMed]

77. He, X.; Wang, Y.; Zhu, J.; Orloff, M.; Eng, C. Resveratrol Enhances the Anti-tumor Activity of the mTOR Inhibitor Rapamycin in Multiple Breast Cancer Cell Lines Mainly by Suppressing Rapamycin-induced AKT Signaling. Cancer Lett. 2011, 301, 168-176. [CrossRef]

78. Colin, D.; Limagne, E.; Jeanningros, S.; Jacquel, A.; Lizard, G.; Athias, A.; Gambert, P.; Hichami, A.; Latruffe, N.; Solary, E.; et al. Endocytosis of Resveratrol via Lipid Rafts and Activation of Downstream Signaling Pathways in Cancer Cells. Cancer Prev. Res. 2011, 4, 1095-1106. [CrossRef]

79. Pozo-Guisado, E.; Merino, J.M.; Mulero-Navarro, S.; Lorenzo-Benayas, M.J.; Centeno, F.; Alvarez-Barrientos, A.; Fernandez-Salguero, P.M.; Salguero, P.M. Resveratrol-induced Apoptosis in MCF-7 Human Breast Cancer Cells Involves a Caspase-independent Mechanism with Downregulation of Bcl-2 and NF-kappaB. Int. J. Cancer 2005, 115, 74-84. [CrossRef]

80. Benitez, D.A.; Hermoso, M.A.; Pozo-Guisado, E.; Fernández-Salguero, P.M.; Castellón, E.A. Regulation of Cell Survival by Resveratrol Involves Inhibition of NF Kappa B-regulated Gene Expression in Prostate Cancer Cells. Prostate 2009, 69, 1045-1054. [CrossRef]

81. Bhardwaj, A.; Sethi, G.; Vadhan-Raj, S.; Bueso-Ramos, C.; Takada, Y.; Gaur, U.; Nair, A.S.; Shishodia, S.; Aggarwal, B.B. Resveratrol Inhibits Proliferation, Induces Apoptosis, and Overcomes Chemoresistance through Down-regulation of STAT3 and Nuclear Factor-kappaB-regulated Antiapoptotic and Cell Survival Gene Products in Human Multiple Myeloma Cells. Blood 2007, 109, 2293-2302. [CrossRef] [PubMed]

82. Siveen, K.S.; Sikka, S.; Surana, R.; Dai, X.; Zhang, J.; Kumar, A.P.; Tan, B.K.; Sethi, G.; Bishayee, A. Targeting the STAT3 Signaling Pathway in Cancer: Role of Synthetic and Natural Inhibitors. Biochim. Biophys. Acta 2014, 1845, 136-154. [CrossRef]

83. Yu, H.; Pardoll, D.; Jove, R. STATs in Cancer Inflammation and Immunity: A Leading Role for STAT3. Nat. Rev. Cancer 2009, 9, 798-809. [CrossRef] [PubMed]

84. Rajasekaran, D.; Elavarasan, J.; Sivalingam, M.; Ganapathy, E.; Kumar, A.; Kalpana, K.; Sakthisekaran, D. Resveratrol Interferes with N-nitrosodiethylamine-induced Hepatocellular Carcinoma at Early and Advanced Stages in Male Wistar Rats. Mol. Med. Rep. 2011, 4, 1211-1217. [CrossRef]

85. Bishayee, A.; Dhir, N. Resveratrol-mediated Chemoprevention of Diethylnitrosamine-initiated Hepatocarcinogenesis: Inhibition of Cell Proliferation and Induction of Apoptosis. Chem. Biol. Interact. 2009, 179, 131-144. [CrossRef]

86. Wu, X.; Li, C.; Xing, G.; Qi, X.; Ren, J. Resveratrol Downregulates Cyp2e1 and Attenuates Chemically Induced Hepatocarcinogenesis in SD Rats. J. Toxicol. Pathol. 2013, 26, 385-392. [CrossRef] [PubMed]

87. Teng, Y.C.; Shen, Z.Q.; Kao, C.H.; Tsai, T.F. Hepatocellular Carcinoma Mouse Models: Hepatitis B Virus-associated Hepatocarcinogenesis and Haploinsufficient Tumor Suppressor Genes. World J. Gastroenterol. 2016, 22, 300-325. [CrossRef]

88. Mbimba, T.; Awale, P.; Bhatia, D.; Geldenhuys, W.J.; Darvesh, A.S.; Carroll, R.T.; Bishayee, A. Alteration of Hepatic Proinflammatory Cytokines is Involved in the Resveratrol-mediated Chemoprevention of Chemically-induced Hepatocarcinogenesis. Curr. Pharm. Biotechnol. 2012, 13, 229-234. [CrossRef] [PubMed]

89. Talib, W.H.; Alsayed, A.R.; Farhan, F.; Al Kury, L.T. Resveratrol and Tumor Microenvironment: Mechanistic Basis and Therapeutic Targets. Molecules 2020, 25, 4282. [CrossRef]

90. Yu, L.; Sun, Z.J.; Wu, S.L.; Pan, C.E. Effect of Resveratrol on Cell Cycle Proteins in Murine Transplantable Liver Cancer. World J. Gastroenterol. 2003, 9, 2341-2343. [CrossRef]

91. Miura, D.; Miura, Y.; Yagasaki, K. Restoration by Prostaglandins E(2) and F (2) (alpha) of Resveratrol-Induced Suppression of Hepatoma Cell Invasion in Culture. Cytotechnology 2003, 43, 155-159. [CrossRef] [PubMed]

92. Notas, G.; Nifli, A.P.; Kampa, M.; Vercauteren, J.; Kouroumalis, E.; Castanas, E. Resveratrol Exerts Its Antiproliferative Effect on HepG2 Hepatocellular Carcinoma Cells, by Inducing Cell Cycle Arrest, and NOS Activation. Biochim. Biophys. Acta 2006, 1760, 1657-1666. [CrossRef]

93. Yonamine, C.Y.; Pinheiro-Machado, E.; Michalani, M.L.; Alves-Wagner, A.B.; Esteves, J.V.; Freitas, H.S.; Machado, U.F. Resveratrol Improves Glycemic Control in Type 2 Diabetic Obese Mice by Regulating Glucose Transporter Expression in Skeletal Muscle and Liver. Molecules 2017, 22, 1180. [CrossRef] [PubMed]

94. Szkudelska, K.; Deniziak, M.; Hertig, I.; Wojciechowicz, T.; Tyczewska, M.; Jaroszewska, M.; Szkudelski, T. Effects of Resveratrol in Goto-Kakizaki Rat, a Model of Type 2 Diabetes. Nutrients 2019, 11, 2488. [CrossRef] [PubMed]

95. Luo, G.; Huang, B.; Qiu, X.; Xiao, L.; Wang, N.; Gao, Q.; Yang, W.; Hao, L. Resveratrol Attenuates Excessive Ethanol Exposure Induced Insulin Resistance in Rats via Improving NAD. Mol. Nutr. Food Res. 2017, 61. [CrossRef]

96. Rehman, K.; Saeed, K.; Munawar, S.M.; Akash, M.S.H. Resveratrol Regulates Hyperglycemia-induced Modulations in Experimental Diabetic Animal Model. Biomed. Pharmacother. 2018, 102, 140-146. [CrossRef]

97. Sebai, H.; Sani, M.; Yacoubi, M.T.; Aouani, E.; Ghanem-Boughanmi, N.; Ben-Attia, M. Resveratrol, a Red Wine Polyphenol, Attenuates Lipopolysaccharide-induced Oxidative Stress in Rat Liver. Ecotoxicol. Environ. Saf. 2010, 73, 1078-1083. [CrossRef] [PubMed]

98. Rocha, K.K.; Souza, G.A.; Ebaid, G.X.; Seiva, F.R.; Cataneo, A.C.; Novelli, E.L. Resveratrol Toxicity: Effects on Risk Factors for Atherosclerosis and Hepatic Oxidative Stress in Standard and High-fat Diets. Food Chem. Toxicol. 2009, 47, 1362-1367. [CrossRef] 
99. Palsamy, P.; Subramanian, S. Resveratrol, a Natural Phytoalexin, Normalizes Hyperglycemia in Streptozotocin-nicotinamide Induced Experimental Diabetic Rats. Biomed. Pharmacother. 2008, 62, 598-605. [CrossRef] [PubMed]

100. Rai, R.C.; Bagul, P.K.; Banerjee, S.K. NLRP3 Inflammasome Drives Inflammation in High Fructose Fed Diabetic Rat Liver: Effect of Resveratrol and Metformin. Life Sci. 2020, 253, 117727. [CrossRef]

101. Oyenihi, O.R.; Oyenihi, A.B.; Adeyanju, A.A.; Oguntibeju, O.O. Antidiabetic Effects of Resveratrol: The Way Forward in Its Clinical Utility. J. Diabetes Res. 2016, 2016, 9737483. [CrossRef]

102. Rivera, H.; Shibayama, M.; Tsutsumi, V.; Perez-Alvarez, V.; Muriel, P. Resveratrol and trimethylated resveratrol protect from acute liver damage induced by CCl4 in the rat. J. Appl. Toxicol. 2008, 28, 147-155. [CrossRef]

103. Mohseni, R.; Arab Sadeghabadi, Z.; Goodarzi, M.T.; Karimi, J. Co-administration of Resveratrol and Beta-aminopropionitrile Attenuates Liver Fibrosis Development via Targeting Lysyl Oxidase in CCl. Immunopharmacol. Immunotoxicol. 2019, 41, 644-651. [CrossRef] [PubMed]

104. Yu, B.; Qin, S.Y.; Hu, B.L.; Qin, Q.Y.; Jiang, H.X.; Luo, W. Resveratrol Improves CCL4-induced Liver Fibrosis in Mouse by Upregulating Endogenous IL-10 to Reprogramme Macrophages Phenotype from M(LPS) to M(IL-4). Biomed. Pharmacother. 2019, 117, 109110. [CrossRef] [PubMed]

105. Faghihzadeh, F.; Hekmatdoost, A.; Adibi, P. Resveratrol and Liver: A Systematic Review. J. Res. Med. Sci. 2015, 20, 797-810. [CrossRef]

106. Vairappan, B.; Sundhar, M.; Srinivas, B.H. Resveratrol Restores Neuronal Tight Junction Proteins Through Correction of Ammonia and Inflammation in CCl. Mol. Neurobiol. 2019, 56, 4718-4729. [CrossRef]

107. Cheng, K.; Yan, E.; Song, Z.; Li, S.; Zhang, H.; Zhang, L.; Wang, C.; Wang, T. Protective Effect of Resveratrol Against Hepatic Damage Induced by Heat Stress in a Rat Model is Associated with the Regulation of Oxidative Stress and Inflammation. J. Therm. Biol. 2019, 82, 70-75. [CrossRef]

108. Filardo, S.; Di Pietro, M.; Mastromarino, P.; Sessa, R. Therapeutic Potential of Resveratrol Against Emerging Respiratory Viral Infections. Pharmacol. Ther. 2020, 214, 107613. [CrossRef] [PubMed]

109. Date, A.A.; Destache, C.J. Natural Polyphenols: Potential in the Prevention of Sexually Transmitted Viral Infections. Drug Discov. Today 2016, 21, 333-341. [CrossRef]

110. Yang, T.; Li, S.; Zhang, X.; Pang, X.; Lin, Q.; Cao, J. Resveratrol, Sirtuins, and Viruses. Rev. Med. Virol. 2015, 25, 431-445. [CrossRef]

111. Annunziata, G.; Maisto, M.; Schisano, C.; Ciampaglia, R.; Narciso, V.; Tenore, G.C.; Novellino, E. Resveratrol as a Novel Anti-Herpes Simplex Virus Nutraceutical Agent: An Overview. Viruses 2018, 10, 473. [CrossRef] [PubMed]

112. Nakamura, M.; Saito, H.; Ikeda, M.; Hokari, R.; Kato, N.; Hibi, T.; Miura, S. An Antioxidant Resveratrol Significantly Enhanced Replication of Hepatitis C Virus. World J. Gastroenterol. 2010, 16, 184-192. [CrossRef] [PubMed]

113. Jiang, L.; Gu, Y.; Ye, J.; Liu, F.; Zhao, Y.; Wang, C.; Xu, Y.; Cao, X.; Zhang, L.; Dong, W.; et al. Resveratrol Prevents Hepatic Steatosis Induced by Hepatitis C Virus Core Protein. Biotechnol. Lett. 2012, 34, 2205-2212. [CrossRef] [PubMed]

114. Deng, J.J.; Kong, K.E.; Gao, W.W.; Tang, H.V.; Chaudhary, V.; Cheng, Y.; Zhou, J.; Chan, C.P.; Wong, D.K.; Yuen, M.F.; et al Interplay between SIRT1 and Hepatitis B Virus X Protein in the Activation of Viral Transcription. Biochim. Biophys. Acta Gene. Regul. Mech. 2017, 1860, 491-501. [CrossRef]

115. Park, S.; Lim, J.; Kim, J.R.; Cho, S. Inhibitory Effects of Resveratrol on Hepatitis B Virus X Protein-induced Hepatocellular Carcinoma. J. Vet. Sci. 2017, 18, 419-429. [CrossRef]

116. Larson, A.M.; Polson, J.; Fontana, R.J.; Davern, T.J.; Lalani, E.; Hynan, L.S.; Reisch, J.S.; Schiødt, F.V.; Ostapowicz, G.; Shakil, A.O.; et al. Acetaminophen-induced Acute Liver Failure: Results of a United States Multicenter, Prospective Study. Hepatology 2005, 42, 1364-1372. [CrossRef]

117. Sheen, C.L.; Dillon, J.F.; Bateman, D.N.; Simpson, K.J.; Macdonald, T.M. Paracetamol Toxicity: Epidemiology, Prevention and Costs to the Health-care System. QJM 2002, 95, 609-619. [CrossRef]

118. Fontana, R.J. Acute Liver Failure Including Acetaminophen Overdose. Med. Clin. North Am. 2008, 92, 761-794. [CrossRef]

119. Elbe, H.; Gul, M.; Cetin, A.; Taslidere, E.; Ozyalin, F.; Turkoz, Y.; Otlu, A. Resveratrol Reduces Light and Electron Microscopic Changes in Acetaminophen-induced Hepatotoxicity in Rats: Role of iNOS Expression. Ultrastruct. Pathol. 2018, 42, 39-48. [CrossRef] [PubMed]

120. Heard, K.J. Acetylcysteine for Acetaminophen Poisoning. N. Engl. J. Med. 2008, 359, 285-292. [CrossRef]

121. Linden, C.H.; Rumack, B.H. Acetaminophen Overdose. Emerg. Med. Clin. N. Am. 1984, 2, 103-119. [CrossRef]

122. Sener, G.; Toklu, H.Z.; Sehirli, A.O.; Velioğlu-Oğünç, A.; Cetinel, S.; Gedik, N. Protective Effects of Resveratrol Against Acetaminophen-induced Toxicity in Mice. Hepatol. Res. 2006, 35, 62-68. [CrossRef]

123. Masubuchi, Y.; Sugiyama, S.; Horie, T. Th1/Th2 Cytokine Balance as a Determinant of Acetaminophen-induced Liver Injury. Chem. Biol. Interact. 2009, 179, 273-279. [CrossRef]

124. Oliva, J.; French, B.A.; Li, J.; Bardag-Gorce, F.; Fu, P.; French, S.W. Sirt1 is Involved in Energy Metabolism: The Role of Chronic Ethanol Feeding and Resveratrol. Exp. Mol. Pathol. 2008, 85, 155-159. [CrossRef]

125. Li, S.; Tan, H.Y.; Wang, N.; Zhang, Z.J.; Lao, L.; Wong, C.W.; Feng, Y. The Role of Oxidative Stress and Antioxidants in Liver Diseases. Int. J. Mol. Sci. 2015, 16, 26087-26124. [CrossRef]

126. Ballardini, G.; De Raffele, E.; Groff, P.; Bioulac-Sage, P.; Grassi, A.; Ghetti, S.; Susca, M.; Strazzabosco, M.; Bellusci, R.; Iemmolo, R.M.; et al. Timing of Reinfection and Mechanisms of Hepatocellular Damage in Transplanted Hepatitis C Virusreinfected Liver. Liver Transpl. 2002, 8, 10-20. [CrossRef] [PubMed] 
127. Strazzabosco, M.; Allen, J.I.; Teisberg, E.O. Value-based Care in Hepatology. Hepatology 2017, 65, 1749-1755. [CrossRef] [PubMed]

128. Lieber, C.S. Alcoholic Fatty Liver: Its Pathogenesis and Mechanism of Progression to Inflammation and Fibrosis. Alcohol 2004, 34, 9-19. [CrossRef]

129. Lieber, C.S. Metabolism of Alcohol. Clin. Liver Dis. 2005, 9, 1-35. [CrossRef]

130. Lieber, C.S. Pathogenesis and Treatment of Alcoholic Liver Disease: Progress over the Last 50 Years. Rocz. Akad. Med. Bialymst. 2005, 50, 7-20.

131. Bujanda, L.; García-Barcina, M.; Gutiérrez-de Juan, V.; Bidaurrazaga, J.; de Luco, M.F.; Gutiérrez-Stampa, M.; Larzabal, M.; Hijona, E.; Sarasqueta, C.; Echenique-Elizondo, M.; et al. Effect of Resveratrol on Alcohol-induced Mortality and Liver Lesions in Mice. BMC Gastroenterol. 2006, 6, 35. [CrossRef] [PubMed]

132. Kasdallah-Grissa, A.; Mornagui, B.; Aouani, E.; Hammami, M.; Gharbi, N.; Kamoun, A.; El-Fazaa, S. Protective Effect of Resveratrol on Ethanol-induced Lipid Peroxidation in Rats. Alcohol Alcohol. 2006, 41, 236-239. [CrossRef] [PubMed]

133. Kasdallah-Grissa, A.; Mornagui, B.; Aouani, E.; Hammami, M.; El May, M.; Gharbi, N.; Kamoun, A.; El-Fazaâ, S. Resveratrol, a Red Wine Polyphenol, Attenuates Ethanol-induced Oxidative Stress in Rat Liver. Life Sci. 2007, 80, 1033-1039. [CrossRef] [PubMed]

134. Eybl, V.; Kotyzova, D.; Koutensky, J. Comparative Study of Natural Antioxidants-Curcumin, Resveratrol and Melatonin-in Cadmium-induced Oxidative Damage in Mice. Toxicology 2006, 225, 150-156. [CrossRef] [PubMed]

135. Meng, C.Y.; Han, Y.F.; Liu, Y.L.; Gao, H.X.; Ren, Y.Y.; Qian, Q.Z.; Wang, Q.; Li, Q.Z. Resveratrol Alleviate the Injury of Mice Liver Induced by Cadmium Sulfide Nanoparticles. Kaohsiung J. Med. Sci. 2019, 35, 297-302. [CrossRef] [PubMed]

136. Sehirli, O.; Tozan, A.; Omurtag, G.Z.; Cetinel, S.; Contuk, G.; Gedik, N.; Sener, G. Protective Effect of Resveratrol against Naphthalene-induced Oxidative Stress in Mice. Ecotoxicol. Environ. Saf. 2008, 71, 301-308. [CrossRef]

137. Upadhyay, G.; Singh, A.K.; Kumar, A.; Prakash, O.; Singh, M.P. Resveratrol Modulates Pyrogallol-induced Changes in Hepatic Toxicity Markers, Xenobiotic Metabolizing Enzymes and Oxidative Stress. Eur. J. Pharmacol. 2008, 596, 146-152. [CrossRef]

138. Farghali, H.; Cerný, D.; Kameníková, L.; Martínek, J.; Horínek, A.; Kmonícková, E.; Zídek, Z. Resveratrol Attenuates Lipopolysaccharide-induced Hepatitis in D-galactosamine Sensitized Rats: Role of Nitric Oxide Synthase 2 and Heme Oxygenase-1. Nitric Oxide 2009, 21, 216-225. [CrossRef]

139. Qian, J.; Zha, L.; Wang, B.; Zhang, C.; Hong, L.; Chen, W. Synthesis, Cytotoxicity and Liver Targeting of 3-O- $\beta$-D-Galactosylated Resveratrol. J. Pharm. Pharmacol. 2019, 71, 929-936. [CrossRef]

140. Sun, S.; Zhang, M.; Yang, Q.; Shen, Z.; Chen, J.; Yu, B.; Wang, H.; Qu, J.; Pang, D.; Ren, W.; et al. Resveratrol Suppresses Lipoprotein-associated Phospholipase A. Mol. Nutr. Food Res. 2017, 61. [CrossRef] [PubMed]

141. Huminiecki, L.; Atanasov, A.G.; Horbańczuk, J. Etiology of Atherosclerosis Informs Choice of Animal Models and Tissues for Initial Functional Genomic Studies of Resveratrol. Pharmacol. Res. 2020, 156, 104598. [CrossRef]

142. Fernández-Quintela, A.; Milton-Laskibar, I.; González, M.; Portillo, M.P. Antiobesity Effects of Resveratrol: Which Tissues are Involved? Ann. NY Acad. Sci. 2017, 1403, 118-131. [CrossRef] [PubMed]

143. Wang, P.; Gao, J.; Ke, W.; Wang, J.; Li, D.; Liu, R.; Jia, Y.; Wang, X.; Chen, X.; Chen, F.; et al. Resveratrol Reduces Obesity in High-fat Diet-fed Mice via Modulating the Composition and Metabolic Function of the Gut Microbiota. Free Radic. Biol. Med. 2020, 156, 83-98. [CrossRef]

144. Xu, L.; Wang, R.; Liu, H.; Wang, J.; Mang, J.; Xu, Z. Resveratrol Treatment Is Associated with Lipid Regulation and Inhibition of Lipoprotein-Associated Phospholipase A2 (Lp-PLA2) in Rabbits Fed a High-Fat Diet. Evid. Based Complement. Alternat. Med. 2020, 2020, 9641582. [CrossRef] [PubMed]

145. Cheng, K.; Song, Z.; Zhang, H.; Li, S.; Wang, C.; Zhang, L.; Wang, T. The Therapeutic Effects of Resveratrol on Hepatic Steatosis in High-fat Diet-induced Obese Mice by Improving Oxidative Stress, Inflammation and Lipid-related Gene Transcriptional Expression. Med. Mol. Morphol. 2019, 52, 187-197. [CrossRef] [PubMed]

146. Ahn, J.; Cho, I.; Kim, S.; Kwon, D.; Ha, T. Dietary Resveratrol Alters Lipid Metabolism-related Gene Expression of Mice on an Atherogenic Diet. J. Hepatol. 2008, 49, 1019-1028. [CrossRef]

147. Meza-Torres, C.; Hernández-Camacho, J.D.; Cortés-Rodríguez, A.B.; Fang, L.; Bui Thanh, T.; Rodríguez-Bies, E.; Navas, P.; López-Lluch, G. Resveratrol Regulates the Expression of Genes Involved in CoQ Synthesis in Liver in Mice Fed with High Fat Diet. Antioxidants 2020, 9, 431. [CrossRef]

148. Cho, I.J.; Ahn, J.Y.; Kim, S.; Choi, M.S.; Ha, T.Y. Resveratrol Attenuates the Expression of HMG-CoA Reductase mRNA in Hamsters. Biochem. Biophys. Res. Commun. 2008, 367, 190-194. [CrossRef]

149. Rašković, A.; Ćućuz, V.; Torović, L.; Tomas, A.; Gojković-Bukarica, L.; Ćebović, T.; Milijašević, B.; Stilinović, N.; Cvejić Hogervorst, J. Resveratrol Supplementation Improves Metabolic Control in Rats with Induced Hyperlipidemia and Type 2 Diabetes. Saudi Pharm. J. 2019, 27, 1036-1043. [CrossRef] [PubMed]

150. Deschênes, M.; Belle, S.H.; Krom, R.A.; Zetterman, R.K.; Lake, J.R. Early Allograft Dysfunction after Liver Transplantation: A Definition and Predictors of Outcome. National Institute of Diabetes and Digestive and Kidney Diseases Liver Transplantation Database. Transplantation 1998, 66, 302-310. [CrossRef]

151. Plin, C.; Tillement, J.P.; Berdeaux, A.; Morin, D. Resveratrol Protects against Cold Ischemia-warm Reoxygenation-induced Damages to Mitochondria and Cells in Rat Liver. Eur. J. Pharmacol. 2005, 528, 162-168. [CrossRef] 
152. Yu, S.; Zhou, X.; Xiang, H.; Wang, S.; Cui, Z.; Zhou, J. Resveratrol Reduced Liver Damage after Liver Resection in a Rat Model by Upregulating Sirtuin 1 (SIRT1) and Inhibiting the Acetylation of High Mobility Group Box 1 (HMGB1). Med. Sci. Monit. 2019, 25, 3212-3220. [CrossRef] [PubMed]

153. Gedik, E.; Girgin, S.; Ozturk, H.; Obay, B.D.; Buyukbayram, H. Resveratrol Attenuates Oxidative Stress and Histological Alterations induced by Liver Ischemia/Reperfusion in Rats. World J. Gastroenterol. 2008, 14, 7101-7106. [CrossRef]

154. Hassan-Khabbar, S.; Vamy, M.; Cottart, C.H.; Wendum, D.; Vibert, F.; Savouret, J.F.; Thérond, P.; Clot, J.P.; Waligora, A.J.; Nivet-Antoine, V. Protective Effect of Post-ischemic Treatment with Trans-resveratrol on Cytokine Production and Neutrophil Recruitment by Rat Liver. Biochimie 2010, 92, 405-410. [CrossRef] [PubMed]

155. Wu, S.L.; Yu, L.; Pan, C.E.; Jiao, X.Y.; Lv, Y.; Fu, J.; Meng, K.W. Apoptosis of Lymphocytes in Allograft in a Rat Liver Transplantation Model Induced by Resveratrol. Pharmacol. Res. 2006, 54, 19-23. [CrossRef] [PubMed]

156. Kirimlioglu, H.; Ecevit, A.; Yilmaz, S.; Kirimlioglu, V.; Karabulut, A.B. Effect of Resveratrol and Melatonin on Oxidative Stress Enzymes, Regeneration, and Hepatocyte Ultrastructure in Rats Subjected to 70\% Partial Hepatectomy. Transplant. Proc. 2008, 40, 285-289. [CrossRef] [PubMed]

157. Velioğlu-Oğünç, A.; Sehirli, O.; Toklu, H.Z.; Ozyurt, H.; Mayadağli, A.; Ekşioğlu-Demiralp, E.; Erzik, C.; Cetinel, S.; Yeğen, B.C.; Sener, G. Resveratrol Protects against Irradiation-induced Hepatic and Ileal Damage via Its Anti-oxidative Activity. Free Radic. Res. 2009, 43, 1060-1071. [CrossRef]

158. Ye, Q.; Zou, B.; Yeo, Y.H.; Li, J.; Huang, D.Q.; Wu, Y.; Yang, H.; Liu, C.; Kam, L.Y.; Tan, X.X.E.; et al. Global Prevalence, Incidence, and Outcomes of Non-obese or Lean Non-alcoholic Fatty Liver Disease: A Systematic Review and Meta-analysis. Lancet Gastroenterol. Hepatol. 2020, 5, 739-752. [CrossRef]

159. Jennison, E.; Patel, J.; Scorletti, E.; Byrne, C.D. Diagnosis and Management of Non-alcoholic Fatty Liver Disease. Postgrad. Med. J. 2019, 95, 314-322. [CrossRef] [PubMed]

160. Makri, E.; Goulas, A.; Polyzos, S.A. Epidemiology, Pathogenesis, Diagnosis and Emerging Treatment of Nonalcoholic Fatty Liver Disease. Arch. Med. Res. 2020. [CrossRef]

161. Wijarnpreecha, K.; Aby, E.S.; Ahmed, A.; Kim, D. Evaluation and Management of Extrahepatic Manifestations of Nonalcoholic Fatty Liver Disease. Clin. Mol. Hepatol. 2020. [CrossRef]

162. Mikolasevic, I.; Filipec-Kanizaj, T.; Mijic, M.; Jakopcic, I.; Milic, S.; Hrstic, I.; Sobocan, N.; Stimac, D.; Burra, P. Nonalcoholic Fatty Liver Disease and Liver Transplantation-Where Do We Stand? World J. Gastroenterol. 2018, 24, 1491-1506. [CrossRef] [PubMed]

163. Targher, G.; Byrne, C.D.; Tilg, H. NAFLD and Increased Risk of Cardiovascular Disease: Clinical Associations, Pathophysiological Mechanisms and Pharmacological Implications. Gut 2020, 69, 1691-1705. [CrossRef]

164. Ismaiel, A.; Dumitraşcu, D.L. Cardiovascular Risk in Fatty Liver Disease: The Liver-Heart Axis-Literature Review. Front. Med. 2019, 6, 202. [CrossRef] [PubMed]

165. Kantartzis, K.; Fritsche, L.; Bombrich, M.; Machann, J.; Schick, F.; Staiger, H.; Kunz, I.; Schoop, R.; Lehn-Stefan, A.; Heni, M.; et al. Effects of Resveratrol Supplementation on Liver Fat Content in Overweight and Insulin-resistant Subjects: A Randomized, Double-blind, Placebo-controlled Clinical Trial. Diabetes Obes. Metab. 2018, 20, 1793-1797. [CrossRef]

166. Cicero, A.F.G.; Fogacci, F.; Banach, M. Botanicals and Phytochemicals Active on Cognitive Decline: The Clinical Evidence. Pharmacol. Res. 2018, 130, 204-212. [CrossRef] [PubMed]

167. Wei, S.; Yu, X. Efficacy of Resveratrol Supplementation on Liver Enzymes in Patients with Non-alcoholic Fatty Liver Disease: A Systematic Review and Meta-analysis. Complement. Ther. Med. 2020, 57, 102635. [CrossRef]

168. Asghari, S.; Rafraf, M.; Farzin, L.; Asghari-Jafarabadi, M.; Ghavami, S.M.; Somi, M.H. Effects of Pharmacologic Dose of Resveratrol Supplementation on Oxidative/Antioxidative Status Biomarkers in Nonalcoholic Fatty Liver Disease Patients: A Randomized, Double-Blind, Placebo-Controlled Trial. Adv. Pharm. Bull. 2018, 8, 307-317. [CrossRef]

169. Rafiee, S.; Mohammadi, H.; Ghavami, A.; Sadeghi, E.; Safari, Z.; Askari, G. Efficacy of Resveratrol Supplementation in Patients with Nonalcoholic Fatty Liver Disease: A Systematic Review and Meta-analysis of Clinical Trials. Complement. Ther. Clin. Pract. 2020, 42, 101281. [CrossRef]

170. Fogacci, F.; Banach, M.; Cicero, A.F.G. Resveratrol Effect on Patients with Non-alcoholic Fatty Liver Disease: A Matter of Dose and Treatment Length. Diabetes Obes. Metab. 2018, 20, 1798-1799. [CrossRef]

171. Theodotou, M.; Fokianos, K.; Moniatis, D.; Kadlenic, R.; Chrysikou, A.; Aristotelous, A.; Mouzouridou, A.; Diakides, J.; Stavrou, E. Effect of Resveratrol on Non-alcoholic Fatty Liver Disease. Exp. Ther. Med. 2019, 18, 559-565. [CrossRef]

172. Cuerda, C.; Luengo, L.M.; Valero, M.A.; Vidal, A.; Burgos, R.; Calvo, F.L.; Martínez, C. Antioxidants and Diabetes Mellitus: Review of the Evidence. Nutr. Hosp. 2011, 26, 68-78.

173. Yılmaz, Z.; Kalaz, E.B.; Aydın, A.F.; Olgaç, V.; Doğru-Abbasoğlu, S.; Uysal, M.; Koçak-Toker, N. The Effect of Resveratrol on Glycation and Oxidation Products in Plasma and Liver of Chronic Methylglyoxal-treated Rats. Pharmacol. Rep. 2018, 70, 584-590. [CrossRef] [PubMed]

174. Bakker, G.C.; van Erk, M.J.; Pellis, L.; Wopereis, S.; Rubingh, C.M.; Cnubben, N.H.; Kooistra, T.; van Ommen, B.; Hendriks, H.F. An Antiinflammatory Dietary Mix Modulates Inflammation and Oxidative and Metabolic Stress in Overweight Men: A Nutrigenomics Approach. Am. J. Clin. Nutr. 2010, 91, 1044-1059. [CrossRef]

175. Brasnyó, P.; Molnár, G.A.; Mohás, M.; Markó, L.; Laczy, B.; Cseh, J.; Mikolás, E.; Szijártó, I.A.; Mérei, A.; Halmai, R.; et al. Resveratrol Improves Insulin Sensitivity, Reduces Oxidative Stress and Activates the Akt Pathway in Type 2 Diabetic Patients. Br. J. Nutr. 2011, 106, 383-389. [CrossRef] 
176. Dash, S.; Xiao, C.; Morgantini, C.; Szeto, L.; Lewis, G.F. High-dose Resveratrol Treatment for 2 Weeks Inhibits Intestinal and Hepatic Lipoprotein Production in Overweight/Obese Men. Arterioscler. Thromb. Vasc. Biol. 2013, 33, 2895-2901. [CrossRef] [PubMed]

177. Timmers, S.; de Ligt, M.; Phielix, E.; van de Weijer, T.; Hansen, J.; Moonen-Kornips, E.; Schaart, G.; Kunz, I.; Hesselink, M.K.; Schrauwen-Hinderling, V.B.; et al. Resveratrol as Add-on Therapy in Subjects With Well-Controlled Type 2 Diabetes: A Randomized Controlled Trial. Diabetes Care 2016, 39, 2211-2217. [CrossRef] [PubMed]

178. Knop, F.K.; Konings, E.; Timmers, S.; Schrauwen, P.; Holst, J.J.; Blaak, E.E. Thirty Days of Resveratrol Supplementation Does not Affect Postprandial Incretin Hormone Responses, but Suppresses Postprandial Glucagon in Obese Subjects. Diabet. Med. 2013, 30, 1214-1218. [CrossRef] [PubMed]

179. Movahed, A.; Raj, P.; Nabipour, I.; Mahmoodi, M.; Ostovar, A.; Kalantarhormozi, M.; Netticadan, T. Efficacy and Safety of Resveratrol in Type 1 Diabetes Patients: A Two-Month Preliminary Exploratory Trial. Nutrients 2020, 12, 161. [CrossRef]

180. Hosseini, H.; Koushki, M.; Khodabandehloo, H.; Fathi, M.; Panahi, G.; Teimouri, M.; Majidi, Z.; Meshkani, R. The Effect of Resveratrol Supplementation on C-reactive Protein (CRP) in Type 2 Diabetic Patients: Results from a Systematic Review and Meta-analysis of Randomized Controlled Trials. Complement. Ther. Med. 2020, 49, 102251. [CrossRef]

181. Zhang, B.; Yin, X.; Sui, S. Resveratrol Inhibited the Progression of Human Hepatocellular Carcinoma by Inducing Autophagy via Regulating p53 and the Phosphoinositide 3-kinase/protein Kinase B Pathway. Oncol. Rep. 2018, 40, 2758-2765. [CrossRef]

182. Grifantini, K. Understanding Pathways of Calorie Restriction: A Way to Prevent Cancer? J. Natl. Cancer. Inst. 2008, 100, 619-621. [CrossRef]

183. Goldberg, D.M.; Yan, J.; Soleas, G.J. Absorption of Three Wine-related Polyphenols in Three Different Matrices by Healthy Subjects. Clin. Biochem. 2003, 36, 79-87. [CrossRef]

184. Howells, L.M.; Berry, D.P.; Elliott, P.J.; Jacobson, E.W.; Hoffmann, E.; Hegarty, B.; Brown, K.; Steward, W.P.; Gescher, A.J Phase I Randomized, Double-blind Pilot Study of Micronized Resveratrol (SRT501) in Patients with Hepatic Metastases-safety, Pharmacokinetics, and Pharmacodynamics. Cancer Prev. Res. 2011, 4, 1419-1425. [CrossRef]

185. Timmers, S.; Konings, E.; Bilet, L.; Houtkooper, R.H.; van de Weijer, T.; Goossens, G.H.; Hoeks, J.; van der Krieken, S.; Ryu, D.; Kersten, S.; et al. Calorie Restriction-like Effects of 30 Days of Resveratrol Supplementation on Energy Metabolism and Metabolic Profile in Obese Humans. Cell Metab. 2011, 14, 612-622. [CrossRef] [PubMed]

186. Most, J.; Timmers, S.; Warnke, I.; Jocken, J.W.; van Boekschoten, M.; de Groot, P.; Bendik, I.; Schrauwen, P.; Goossens, G.H.; Blaak, E.E. Combined Epigallocatechin-3-gallate and Resveratrol Supplementation for 12 wk Increases Mitochondrial Capacity and Fat Oxidation, but not Insulin Sensitivity, in Obese Humans: A Randomized Controlled Trial. Am. J. Clin. Nutr. 2016, 104, 215-227. [CrossRef]

187. Akbari, M.; Tamtaji, O.R.; Lankarani, K.B.; Tabrizi, R.; Dadgostar, E.; Haghighat, N.; Kolahdooz, F.; Ghaderi, A.; Mansournia, M.A.; Asemi, Z. The Effects of Resveratrol on Lipid Profiles and Liver Enzymes in Patients with Metabolic Syndrome and Related Disorders: A Systematic Review and Meta-analysis of Randomized Controlled Trials. Lipids Health Dis. 2020, 19, 25. [CrossRef] [PubMed]

188. Gualdoni, G.A.; Kovarik, J.J.; Hofer, J.; Dose, F.; Pignitter, M.; Doberer, D.; Steinberger, P.; Somoza, V.; Wolzt, M.; Zlabinger, G.J. Resveratrol Enhances TNF- $\alpha$ Production in Human Monocytes upon Bacterial Stimulation. Biochim. Biophys. Acta 2014, 1840, 95-105. [CrossRef]

189. Espinoza, J.L.; Trung, L.Q.; Inaoka, P.T.; Yamada, K.; An, D.T.; Mizuno, S.; Nakao, S.; Takami, A. The Repeated Administration of Resveratrol Has Measurable Effects on Circulating T-Cell Subsets in Humans. Oxid. Med. Cell. Longev. 2017, $2017,6781872$. [CrossRef] [PubMed]

190. Evans, H.M.; Howe, P.R.; Wong, R.H. Effects of Resveratrol on Cognitive Performance, Mood and Cerebrovascular Function in Post-Menopausal Women; A 14-Week Randomised Placebo-Controlled Intervention Trial. Nutrients 2017, 9, 27. [CrossRef] [PubMed]

191. Lin, C.T.; Sun, X.Y.; Lin, A.X. Supplementation with High-dose Trans-resveratrol Improves Ultrafiltration in Peritoneal Dialysis Patients: A Prospective, Randomized, Double-blind Study. Ren. Fail. 2016, 38, 214-221. [CrossRef] [PubMed]

192. Rotches-Ribalta, M.; Andres-Lacueva, C.; Estruch, R.; Escribano, E.; Urpi-Sarda, M. Pharmacokinetics of Resveratrol Metabolic Profile in Healthy Humans after Moderate Consumption of Red Wine and Grape Extract Tablets. Pharmacol. Res. 2012, 66, 375-382. [CrossRef]

193. Almeida, L.; Vaz-da-Silva, M.; Falcão, A.; Soares, E.; Costa, R.; Loureiro, A.I.; Fernandes-Lopes, C.; Rocha, J.F.; Nunes, T.; Wright, L.; et al. Pharmacokinetic and Safety Profile of Trans-resveratrol in a Rising Multiple-dose Study in Healthy Volunteers. Mol. Nutr. Food Res. 2009, 53, S7-S15. [CrossRef] [PubMed]

194. Calvo-Castro, L.A.; Schiborr, C.; David, F.; Ehrt, H.; Voggel, J.; Sus, N.; Behnam, D.; Bosy-Westphal, A.; Frank, J. The Oral Bioavailability of Trans-Resveratrol from a Grapevine-Shoot Extract in Healthy Humans is Significantly Increased by Micellar Solubilization. Mol. Nutr. Food Res. 2018, 62, e1701057. [CrossRef]

195. Azachi, M.; Yatuv, R.; Katz, A.; Hagay, Y.; Danon, A. A Novel Red Grape Cells Complex: Health Effects and Bioavailability of Natural Resveratrol. Int. J. Food. Sci. Nutr. 2014, 65, 848-855. [CrossRef] [PubMed]

196. Vaz-da-Silva, M.; Loureiro, A.I.; Falcao, A.; Nunes, T.; Rocha, J.F.; Fernandes-Lopes, C.; Soares, E.; Wright, L.; Almeida, L.; Soares-da-Silva, P. Effect of Food on the Pharmacokinetic Profile of Trans-resveratrol. Int. J. Clin. Pharmacol. Ther. 2008, 46, 564-570. [CrossRef] [PubMed] 